\title{
BioÉTiCA nas Questões da VidA e DA MORTE
}

\author{
Maria Julia Kovács \\ Instituto de Psicologia - USP
}

O presente trabalho discute questões fundamentais acerca do fim da vida $e$ da aproximação da morte. Como pano de fundo, apresenta uma reflexão bioética sobre temas complexos, tais como: qualidade de vida, dignidade no processo de morrer e autonomia nas escolhas em relação à própria vida nos seus momentos finais. $O$ avanço da tecnologia médica favoreceu a cura de doenças e o prolongamento da vida, porém, levada ao exagero, pode fazer com que o sofrimento seja adicionado ao que se propõe ser um benefício, estimulando a discussão sobre questões relativas ao direito de decidir sobre o momento da morte, eutanásia, suicídio assistido e distanásia. A clarificação e a apresentação destes tópicos, sob vários ângulos, são os objetivos deste trabalho. Propõe-se, ainda, a criação de espaços para a discussão multidisciplinar das questões apresentadas.

Descritores: Bioética. Morte. Eutanásia. Cuidados paliativos.

\begin{abstract}
morte no século XXI é vista como tabu, interdita, vergonhosa; por Aoutro lado, o grande desenvolvimento da medicina permitiu a cura de várias doenças e um prolongamento da vida. Entretanto, este desenvolvimento pode levar a um impasse quando se rata de buscar a cura e salvar uma vida, com todo o empenho possível, num contexto de missão impossível: manter uma vida na qual a morte já está presente. Esta atitude de tentar preservar a vida a todo custo é responsável por um dos maiores temores do
\end{abstract}

1 Coordenadora do Laboratório de Estudos sobre a Morte - Departamento de Psicologia da Aprendizagem, do Desenvolvimento e da Personalidade - Instituto de Psicologia da Universidade de São Paulo. Av. Mello Moraes, 1721, Cidade Universit ária - 05508-900 - São Paulo, SP. Endereço eletrônico: mjkorag@usp.br

Psicologia USP, 2003, 14(2), 115-167 
ser humano na atualidade, que é o de ter a sua vida mantida às custas de muito sofrimento, solitário numa UTI, ou quarto de hospital, tendo por companhia apenas tubos e máquinas.

É neste contexto que surge a questão: é possível escolher a forma de morrer? Observa-se o desenvolvimento de um movimento que busca a dignidade no processo de morrer, que não é o apressamento da morte, a eutanásia, nem o prolongamento do processo de morrer com intenso sofrimento, a distanásia.

O problema é que existe uma grande confusão entre estes termos, e o seu esclarecimento se faz necessário. Assim, a bioética do século XXI deve retomá-los, trazendo à tona a necessidade da discussão destas questões com base em alguns princípios que são muito importantes: beneficência, dignidade, competência e autonomia. O movimento dos cuidados paliativos ${ }^{2}$ trouxe de volta, no século XX, a possibilidade de rehumanização do morrer, opondo-se à idéia da morte como o inimigo a ser combatido a todo custo. Ou seja, a morte é vista como parte do processo da vida e, no adoecimento, os tratamentos devem visar à qualidade dessa vida e o bem estar da pessoa, mesmo quando a cura não é possível; mas, frente a essa impossibilidade, nem sempre o prolongamento da vida é o melhor, e não se está falando de eutanásia, como muitos crêem.

Entre as grandes questões sobre o fim da vida, destaco as seguintes:

- $\quad$ Tem a pessoa o direito de decidir sobre sua própria morte, buscando dignidade?

- $\quad$ Pode-se planejar a própria morte?

- $\quad$ Os profissionais de saúde, que têm o dever de cuidar das necessidades dos pacientes, podem atender um pedido para morrer?

2 Movimento de cuidados a pacientes gravemente enfermos, buscando alívio e controle de sintomas. 
- $\quad$ Podem ser interrompidos tratamentos que têm como objetivo apenas o prolongamento da vida, sem garantia da qualidade da mesma?

Whiting (1995-1996) aponta caminhos para algumas respostas a estas questões. Sobre o encerramento da própria vida, a lei não tem o que dizer, uma vez que a decisão é da pessoa e está vinculada a determinantes pessoais e religiosos. Se pensamos em assistência no processo de morrer, aí sim, trata-se de questão legal, porque está envolvida uma proposta homicida, mesmo que por piedade.

Todos esses aspectos tornamse ainda mais complexos quando envolvem uma pessoa inconsciente ou em coma. Em alguns países, existe a possibilidade de se escrever um testamento, ainda em vida, feito de próprio punho, quando ainda se está saudável, ou no início do processo de adoecimento, com referências ao desejo de não ser mantido vivo sob certas circunstâncias. O problema é saber se o testamento, feito quando a pessoa estava saudável, ainda se mantém válido quando adoece, pois, como aponta Hennezel (2001), crises, como é o processo do adoecimento, podem levar a uma adaptação, após o tempo necessário para elaboração das perdas.

No caso de crianças, há também questões complexas envolvidas: será que elas podem expressar o seu desejo de viver ou de morrer, têm competência para decidir? E, se não puderem, quem pode decidir por elas, seus pais ou um tutor? Tenho certeza que ainda não há consenso sobre estas questões.

\section{A bioética - algumas considerações de ordem geral}

Segundo Segre e Cohen (1995), a bioética é o ramo da ética que enfoca questões relativas à vida e à morte, propondo discussões sobre alguns temas, entre os quais: prolongamento da vida, morrer com dignidade, eutanásia e suicídio assistido. 
Segundo os autores, o termo bioética foi apresentado, pela primeira vez, pelo oncologista Potter (1971), na sua obra Bioethics - Bridge to the Future. Nesta obra, propõe uma ponte no trabalho de cientistas e humanistas. Nos primeiros trabalhos na área, havia grande preocupação com valores humanos, cabendo à teologia as linhas mestras. Num segundo momento, a filosofia tomou a frente, numa vertente de secularização. Entre 1985 e 2000, a bioética foi adquirindo um caráter multidisciplinar, envolvendo ciências sociais, direito, antropologia e psicologia, além da teologia. Nas ciências da saúde, surge a preocupação com as condutas médicas, que culminou, em 1962, no que se chamou de Comitê de Deus, ou seja, a escolha de pacientes que serão submetidos a determinados tratamentos em detrimento de outros (Pessini \& Barchifontaine, 1994). Posteriormente, passaram a ter grande importância a relação médico/paciente, os aspectos relativos à autodeterminação, a autonomia e os direitos humanos.

$\mathrm{Na}$ terceira fase das discussões da bioética começam a ter lugar as discussões envolvendo a macropolítica da saúde, a economia e a questão dos excluídos (Anjos, 2002).

As atrocidades cometidas pelo nazismo, na Segunda Guerra Mundial, trazem ênfase à discussão de pesquisas envolvendo seres humanos, as intenções e o sofrimento causado às pessoas, mesmo que em nome da ciência, culminando com o código de Nüremberg, no qual se postula que nenhuma pesquisa possa envolver seres humanos, sem que haja sua autorização explícita. Atualmente, os comitês de ética zelam por estas condições em várias instituições.

Houve, também, um desenvolvimento da bioética vinculada aos seguintes princípios: autonomia, beneficência e justiça, o que Pessini e Barchifontaine (1994) denominaram de trindade bioética.

A autonomia se refere ao respeito à vontade e ao direito de autogovernar-se, favorecendo que a pessoa possa participar ativamente dos cuidados à sua vida. Segundo Fabbro (1999), só se pode falar em exercício de autonomia quando há compartilhamento de conhecimento e informação da equipe de saúde para o paciente, oferecendo dados importantes, em lingua- 
gem acessível, para que qualquer decisão possa ser tomada, garantindo-se a competência de todos os membros envolvidos na situação.

Um aspecto importante a ser apontado, quando nos referimos ao princípio da autonomia, é a constatação de que nos cuidados aos doentes, muitas vezes, ocorre uma relação paternalista, assimétrica, entre eles e os profissionais de saúde: em uma das polaridades está o poder da equipe de saúde e, na outra, a submissão do paciente. Quando se favorece a autonomia, ocorre uma relação simétrica entre profissionais e pacientes, sendo que estes últimos participam de maneira ativa das decisões que envolvem seu tratamento, bem como sua interrupção. Enfim, como já apontei, para que a autonomia possa ser exercida é fundamental que o paciente receba as informações necessárias, que o instrumentalizem e o habilitem para a tomada de decisões, diante das opções existentes em cada situação. Cabe lembrar que, em muitos casos, estamos diante de uma situação conflitiva, na qual várias opções devem ser consideradas - aliás, este é o fundamento das questões éticas. Como aponta Segre (1999), faz-se necessária uma hierarquização desses conflitos, para que se possa buscar uma resposta que atenda às necessidades daqueles que estão sob nossos cuidados.

Considerando as questões sobre o fim da vida, podemos observar que existe uma pluralidade de respostas possíveis e que vários pontos de vista devem ser considerados, não se tratando de um relativismo sem limites.

Um outro ponto que provoca discussões importantes no ramo da bioética é o desenvolvimento da tecnologia médica, o prolongamento da vida, às vezes sem limite, e o dilema entre a sacralidade da vida e uma preocupação com a sua qualidade. Se é a vida, como valor absoluto, que deve ser mantida a todo custo, nada poderá ser feito para a sua abreviação, e deve se evitar a morte a todo custo. Foi o desenvolvimento da tecnologia que favoreceu a manutenção e prolongamento da vida, e então pergunta-se até quando investir em tratamentos e quando interrompê-los. Estes são os dilemas relativos à eutanásia, à distanásia, ao suicídio assistido e ao morrer com dignidade. 
Na década de 1960, com o advento dos transplantes, começaram a ser questionados os limites da vida, mantida com máquinas. $\mathrm{O}$ critério de morte deixa de ser a parada cárdio-respiratória e passa a ser a morte encefálica.

As situações de vida e morte envolvem vários personagens: pacientes, familiares e equipe de saúde, além da instituição hospitalar. Numa relação simétrica, qualquer decisão envolverá todos estes personagens, arrolando-se os prós e os contras de cada uma das opções. Entretanto, na maior parte das instituições hospitalares observa-se a posição paternalista, na qual, baseada no princípio da beneficência, de se fazer o bem e evitar o sofrimento adicional, a equipe age unilateralmente, justificando-se com a idéia de que sabe o que é melhor para o paciente; ou seja, considera que este não está preparado para saber o que é o melhor para si. Assim, a equipe de saúde é a depositária do saber.

Toda esta discussão se torna fundamental quando está em jogo a busca da dignidade, não só durante toda a vida, mas também com a aproximação da morte, envolvendo a valorização das necessidades e a diminuição do sofrimento.

O princípio da justiça envolve a propriedade natural das coisas, a liberdade contratual, a igualdade social e o bem-estar coletivo entendido como equiidade: cada pessoa deve ter suas necessidades atendidas, reconhecendo-se as diferenças e as singularidades, como apontam Fortes (2002) e Garrafa e Porto (2002).

Segundo Pessini e Barchifontaine (1994), a pessoa é o fundamento de toda a reflexão da bioética, considerando-se a alteridade, isto é, a sua relação com outras pessoas. Retomamos a questão da vida, e da sua manutenção a todo custo. Quando se leva em conta apenas a sacralidade, o que importa é a vida, sem entrar no mérito de sua qualidade. Quando a discussão envolve a qualidade do viver, então, não são somente os parâmetros vitais que estão em jogo, mas sim que não haja sofrimento. O que é fundamental não é a extensão da vida e sim sua qualidade. $\mathrm{Na}$ verdade, estas dimensões não são mutuamente exclusivas e contrárias, porém, complementares. Engelhardt (1998) discute a questão da vida biológica e pessoal e a partir destes pontos 
de vista, surgem as questões: quando deve ser definido o início da vida; no momento da concepção, na sua evolução, ou na possibilidade de estabelecer relações? E quando termina a vida; na perda da consciência, na impossibilidade de cuidar de si, quando apenas aparelhos mantêm a vida, ou quando o último parâmetro biológico deixa de se manifestar? São questões que demandam muita reflexão e discussão.

Anjos (2002) aponta a importância de se pensar numa bioética para o terceiro mundo, na qual a justiça para todos é uma questão importante, uma vocação para se pensar naqueles que são os excluídos, os pobres, para quem não se discute a eutanásia voluntária, e sim, a involuntária. Trata-se de um erro conceitual, são aqueles que morrem antes do tempo, não pela sua vontade, mas pela falta de atendimento ade quado e pelas condições subhumanas de vida. É neste contexto que a noção de eqüidade é significativa, ou seja, é fundamental atender um número maior de pessoas nas suas necessidades, tanto na alocação de recursos, quanto na sua qualidade e magnitude. Neste quadro, a teologia tem a sua grande força: a justiça, a solidariedade e a fé.

Garrafa e Porto (2002) trazem a seguinte questão: existe uma ética universal? Se a resposta for positiva, encontram-se, aí, obstáculos intransponíveis, pois uma gama imensa de valores está presente nas grandes questões que atingem a humanidade. Por outro lado, o perigo de não se ter como base alguns valores fundamentais é de se chegar a um relativismo que, em algumas situações, se torna intolerável.

Passo, agora, a apresentar quatro situações específicas, de meu interesse, para as quais a bioética tem voltado sua atenção: pedidos para morrer, eutanásia, suicídio assistido e distanásia. Na sequiência, serão abordados os cuidados paliativos, como opção às três últimas situações nomeadas, e algumas críticas possíveis a eles.

Ao introduzir o assunto, quero ressaltar a importância da clarificação dos termos usados, para que as discussões que envolvem temas tão polêmicos não sejam prejudicadas por diferentes entendimentos. Schramm (2002) aponta que não se trata, apenas, de uma melhor definição dos termos, mas também deve ser observado qual é o posicionamento tomado em cada questão. 
Segundo este autor, só uma definição de morte não esclarece este assunto; é preciso entrar no mérito existencial e filosófico, isto é, o que signif ica fim da vida e por que se quer planejá-lo. A discussão é se existe ou não o direito de determinar o fim da própria vida. $\mathrm{O}$ autor cita Frankl e as suas obras que apontam para a questão do sentido da vida, para a percepção do vazio existencial e para o direito de exercer a liberdade da maneira mais radical, ou seja, decidindo sobre a própria vida.

$\mathrm{O}$ autor afirma que o temor, em relação à legalização da eutanásia, se relaciona a um suposto aumento do poder dos médicos na determinação da morte. Por outro lado, os que a defendem retomam o princípio da autonomia e a priorização do que é qualidade de vida, apontando que na sociedade atual se observa uma desapropriação da morte. Será que o paciente tem direito a pedir para morrer? O direito à auto-determinação é que poderia justificar uma discussão mais aprofundada sobre a questão da eutanásia.

Retomando a questão de esclarecimento, Wooddell e Kaplan (19971998) apontam algumas distinções que devem ser consideradas:

Eutanásia ativa: ação que causa ou acelera a morte.

Eutanásia passiva: a retirada dos procedimentos que prolongam a vida. Esta modalidade, na atualidade, não é mais considerada como eutanásia (grifo meu), desde que diante de um caso irreversível, sem possibilidade de cura e quando o tratamento causa sofrimento adicional. A interrupção dos tratamentos, neste caso, recebe o nome, de ortotanásia, ou seja, a morte na hora certa - distinção ainda ño aceita por muitos profissionais. Segundo Maurice Abiven, diretor da Unidade de Serviços Paliativos do Hospital Universitário de Paris, citado por Zaidhaft (1990, p. 120), não há eutanásia passiva, sendo esta uma expressão inadequada. Há, simplesmente, respeito à natureza.

Eutanásia voluntária: a ação que causa a morte quando há pedido explícito do paciente.

Eutanásia involuntária: ação que leva à morte, sem consentimento explícito do paciente. Neste caso, não deveria mais ser chamada de eutaná- 
sia, e sim, de homicídio; com o atenuante de que é executada para aliviar o sofrimento, possivelmente dos cuidadores, familiares ou profissionais.

Suicídio: ação que o sujeito faz contra si próprio, e que resulta em morte.

Suicídio assistido: quando há ajuda para a realização do suicídio, a pedido do paciente. Esta situação é considerada crime, do ponto de vista legal.

Suicídio passivo: deixar de fazer alguma ação, podendo resultar em morte; por exemplo, não tomar medicação. Esta é uma situação muito difícil de ser comprovada. Falar em suicídio sempre implica na necessidade de uma cuidadosa investigação, já que vários fatores podem estar envolvidos nesta ação.

Há, ainda, outros termos que são usados quando se fala de morrer com dignidade, envolvendo temas como eutanásia e suicídio assistido:

Duplo efeito (double effect): quando uma ação de cuidados é realizada e acaba conduzindo, como efeito secundário, ao óbito. Um exemplo desta situação é a analgesia e sedação, aplicada em pacientes gravemente enfermos, que têm como objetivo principal aliviar os sintomas e promover qualidade de vida, e não provocar a morte, embora esta possa ocorrer.

Testamento em vida, vontade em vida (living will): o paciente escreve o seu testamento em vida, referindo-se ao que gostaria que acontecesse, quando não mais pudesse fazer escolhas e participar de seu tratamento. Este procedimento é muito utilizado quando se trata de um pedido de não ressuscitamento. É um documento legal nos Estados Unidos da América.

Ladeira escorregadia (Slippery slope): trata-se de uma zona de conflito e polêmica, na qual certa decisão pode ter efeitos sobre os quais não se havia pensado anteriormente. Por exemplo: a legalização da eutanásia poderá colocar em risco de morte antecipada (embora este não seja o objetivo explícito) populações vulneráveis, como: idosos, pobres e doentes mentais.

Poder durável de um advogado para cuidados de saúde (Durable powers of attorney for health care): é documento por meio do qual a pessoa 
nomeia outra pessoa para tomar decisões sobre os cuidados de sua saúde, se, e quando ela própria se tornar incapaz de fazê-lo, permitindo, assim, que o médico obtenha de alguém o consentimento informado para algum procedimento ou para interrupção de tratamento.

Assim considerados os diversos graus de ação do paciente, pode-se analisar o grau de envolvimento da equipe médica em questões, tais como conhecimento, cumplicidade e uma ação mais direta da equipe, com conhecimento ou não do paciente.

Estas modalidades não são estanques, mas propõem uma forma de compreensão dos movimentos dos pacientes e médicos na preservação da vida, bem como na possibilidade de induzir a morte.

\section{Pedidos para morrer}

Muitas pessoas, em fase final da doença, pedem para morrer. O que estaria na base destes pedidos, uma dor intolerável ou depressão?

Chochinov et al. (1995) estudaram 200 casos de pacientes em estágio terminal e verificaram que apenas $8,5 \%$ destes pediram que se apressasse a morte e, entre estes, observou-se uma história de depressão e abandono por parte da família.

Vários pedem para morrer porque consideram sua vida insuportável, sentem-se como sobrecarga para a família. Estão internados em hospitais, solitários, abandonados e impotentes diante da vida e da morte. Muitos se referem a um sentimento de falta de controle. Em outros casos, o pedido para morrer está relacionado com o fato de não estarem recebendo cuidados adequados, tendo sua dor subtratada.

Markson (1995) alerta para que não se considerem todos os pedidos para morrer como irracionais, delirantes, ou vindos de uma profunda depressão. Assim, os pedidos nunca devem ser avaliados como questões simples; ao contrário, devem ser escutados e contextualizados, e jamais deveriam receber respostas rápidas e impensadas. Sem dúvida, valores importantes 
são questionados nestes casos, inseridos numa cultura que sacraliza a vida e vê a morte como um inimigo a ser combatido a todo custo.

Por outro lado, sabe-se que muitas pessoas não agüentam mais a vida, mas nada dizem sobre isso. Não imaginam poder falar com seus médicos sobre o assunto, nem sequer se acham no direito de pedir informações sobre seu estado de saúde e prognóstico de suas doenças.

Mishara (1999) observou que a dor e o sofrimento estão na base de inúmeros pedidos para apressar a morte. Também foi encontrada, pelo autor, forte relação com depressão clínica. Observa, ainda, que está havendo maior incidência de pedidos de eutanásia, suicídio e comportamentos autodestrutivos em pessoas com os seguintes problemas psicossociais: depressão, perdas significativas, falta d apoio social e dificuldades em dar conta da vida. Mais recentemente, tem-se observado uma alta relação entre suic ídio e demência. Muitas pessoas pedem para morrer, ou cometem o suicídio, quando se vêem diante da possibilidade de dependência, aliada a um sentimento de perda de dignidade. No caso do câncer e da Aids, os tratamentos podem causar tanto mal estar e desespero que preferem morrer. Segundo Mishara, há maior tolerância da sociedade com os pedidos de eutanásia, quando são manifestos por pacientes gavemente enfermos, mesmo que nem sempre a morte esteja tão próxima ou que não haja nada mais que possa ser feito.

É necessário saber se a pessoa quer, de fato, morrer, observando-se suas atitudes, pedidos e ações. Chochinov et al. (1995), na pesquisa já mencionada, verificaram que $44,5 \%$ dos pacientes falaram que queriam que a morte chegasse logo, mas só 8,5\% fizeram um pedido mais explícito e, destes, $60 \%$ tinham um quadro de depressão clínica. Entretanto, muitos pacie ntes em fase terminal se queixaram de solidão, da falta de presença da família e de dor.

Muitos membros da equipe de saúde não sabem como manejar a dor e outros sintomas incapacitantes, e acabam se afastando destes pacientes. Hennezel (2001) considera que $90 \%$ dos pedidos de eutanásia desapareceriam se os doentes se sentissem menos sós e com menos dor. Para ela é im- 
portante considerar a legitimidade dos pedidos, ou seja, os pacientes poderem falar que estão cansados da vida, que não agüientam mais o sofrimento. Mas ao pedirem que se finalizem os seus sofrimentos, a autora se pergunta: será que para nos apropriarmos de nossa própria morte, é preciso pedir para que alguém nos mate?

Hennezel, explorando o tema, lança um outro olhar para a questão, ao afirmar que, quando o doente pede para morrer, pede também que se olhe para ele, para o seu sofrimento, para que se sinta legitimado na sua dor. Procura também aprofundar a questão, discutindo a diferença entre desejo e necessidade. Para ela, a necessidade é o que está premente, acessível à consciência e demanda uma resolução imediata, como, por exemplo, o alívio da dor. O desejo não é tão claro à consciência. Uma grande dor para o paciente, sensível e atento, é pensar que o enterraram antes do tempo, prevendo sua morte. Nesta situação, antecipa-se, pedindo para morrer antes que o matem. $\mathrm{E}$ a autora afirma que, tanto no pedido para morrer, como na eutanásia, podem estar embutidos uma agressividade inconsciente, uma desilusão de ambos os lados, claros indícios de impotência.

E será que o pedido do paciente para morrer não poderia ser também uma resposta ao olhar de impotência do profissional, que não sabe o que fazer na situação? Como já referi, o pedido para morrer pode ser visto como um pedido de atenção, uma afirmação de que se é humano, que ainda se está vivo. Às vezes, o paciente está tão deformado que não se sente mais vivo, nem é mais visto assim. Não pede obrigatoriamente que se faça algo, mas para que seja visto e ouvido. Não podemos nos esquecer da importância dos últimos momentos de vida para o doente e para os seus familiares.

É importante ressaltar: será que o desejo de morrer está sempre relacionado com sofrimento e depressão? Será que, em alguns casos, não é a constatação de que a vida chegou ao fim? A diferença é que, no primeiro caso, os pacientes exalam tristeza e, no segundo, serenidade.

Há pessoas que não conseguem morrer e pedem ajuda para soltar-se. Morrer pode ser tão tensionante, que não conseguem se libertar. Permitir morrer não é igual a matar. Às vezes, o medo de morrer é tão grande que há 
enorme necessidade de paz, segurança e, à semelhança do parto, é a busca de um contato que não retém e sim liberta. Como o assunto é, certamente, polêmico e não há consenso entre os profissionais envolvidos, aqui estão apenas sendo alinhavadas algumas considerações.

Outro assunto de interessante abordagem é o do testamento em vida (prática que tem aumentado significativamente), no qual é pedido o não ressuscitamento em caso de parada cardíaca - também uma forma de pedir para morrer. É bastante usual, principalmente nos Estados Unidos, segundo Whiting (1995-1996). No Brasil, ainda não temos esta prática estabelecida.

Os testamentos em vida envolvem a recusa de certos tratamentos médicos que têm como objetivo o prolongamento da vida; são feitos pelos pacientes quando conscientes, e deixados com outras pessoas para o momento em que for necessário, seja em caso de inconsciência, ou de qualquer outra impossibilidade de decisão. Mesmo que este documento represente a vontade da pessoa, respeitando-se o princípio da autonomia, é gerador de muita ambivalência, quando se considera a possibilidade de eventual mudança de opinião durante o curso da doença.

Nos EUA, se não tiver sido feito o testamento em vida, os pacientes passarão por procedimentos de ressuscitamento, em caso de parada cardíaca. Segundo Stephen e Grady (1992), um terço destes procedimentos ocorreu contra a vontade dos pacientes, pelo fato de não haver pedido explícito para que não fosse realizado.

Considero que o testamento em vida pode ser instrumento facilitador, quando se trata de tomar uma decisão sobre o que fazer em situação de conflito. O paciente pode, então, clarificar os seus desejos, reduzindo a possibilidade de serem realizados tratamentos contra sua vontade; facilita, também, a situação para a família, quando esta não teve a oportunidade de conversar com ele a respeito deste assunto, e favorece o princípio de autonomia do paciente.

Aliás, os familiares são ambivalentes quando se trata do paciente, mas muitos, quando pensam o que gostariam para si, relatam que prefeririam terminar logo com tudo. 
Hennezel (2001) aponta que muitos familiares acabam pedindo que se apresse a morte do paciente, porque não agüentam ver seu sofrimento; o fim da vida pode ser muito assustador, o paciente pode se tornar um estranho para si mesmo, e para aqueles que lhe são mais próximos. Por outro lado, quando o período final da doença é prolongado, os próprios familiares acabam se esgotando por causa das semanas de vigília ao pé do leto, estimulando os pedidos para o abreviamento da situação.

A equipe de saúde também não sabe o que fazer quando surge o pedido de morte pelo paciente. A tendência mais comum é a de sempre preservar a vida; entretanto, o aumento da expectativa de vida e do tempo de doença, começa a criar pontos de conflito sobre até que ponto é legítimo o prolongamento da vida, às custas de muito sofrimento. Os médicos não se sentem preparados para conversar sobre o assunto e não conseguem lidar com o fato de que o pedido para morrer possa ter uma motivação ligada a um sofrimento intolerável - neste caso, o pedido para morrer seria, basicamente, para alívio. Pesquisa de Chochinov et al. (1995) indicou que 54\% dos médicos entrevistados acham que o pedido é razoável, quando le vam em conta o grau de sofrimento envolvido; entretanto, quando questionados sobre a possibilidade de, eles mesmos, realizarem o ato de apressar a morte, esta porcentagem cai para $33 \%$.

Pesquisas mostraram que $40 \%$ dos médicos entrevistados já receberam, de seus pacientes, pedidos para morrer. Este número de pedidos é significativo e demonstra como o fim de vida pode ser muito penoso. Entretanto, a maioria destes pedidos não resultarou em sua aceitação. Quando os médicos falam da consumação do ato, o método mais utilizado é o dos coquetéis que misturam calmante, anestésico e veneno, e que permitem uma morte tranqüila. A fronteira entre sedação e eutanásia é muito tênue; o que diferencia as duas é a intenção, nem sempre muito clara. Infelizmente, a diferença entre palavras e intenções nem sempre pode ser explicitada.

Hennezel (2001) aponta para a importância de o profissional poder se referir à sua impotência e vulnerabilidade diante do paciente, principalmente quando os tratamentos não estão surtindo os efeitos esperados, mas não sig- 
nifica que se tenha de atender o pedido de apressamento da morte. Confirmando, não prolongar a vida com tratamentos invasivos, permitir morrer, não é igual a matar.

Aponta, também, que vários profissionais não suportam ver o sofrimento de seus pacientes, acabando por atender seu pedido de morte, transformando-se nos anjos da morte, também conhecidos como eutanatólogos. Alguns atos de apressamento da morte podem ser fruto da solidão dos profissionais, que se sentem sem apoio nas tarefas de cuidar dos pacientes em grande sofrimento. Esta solidão pode ocorrer, também, em hospitais ultra movimentados, nos quais os corredores fervem com pessoas correndo de um lado para o outro e, talvez, por isto mesmo sejam chamados de "corredores". Nesta correria ninguém se enxerga e, muitas vezes, nem se sabe o que está acontecendo na sala ao lado.

Em vários hospitais, o fim de vida é pleno de sofrimento, com muitas dores e sem calor humano; pacientes, familiares e enfermeiros abandonados à própria sorte, não sabendo o que fazer, e os últimos tendo mesmo de realizar procedimentos com os quais não concordam.

O que é mais complicado nos hospitais não é a morte em si, mas os dramas até a morte, a agonia. É aí que surge a tentação de aliviar o sofrimento, induzindo a morte. Mishara (1999) observa que houve um aumento de 35\% nos pedidos de eutanásia, de 1990 a 1995. Acredito que este fato esteja diretamente ligado às intervenções médicas, que provocam um prolongamento da vida, sem preocupação equivalente com a qualidade da mesma.

\section{Eutanásia}

Abordo, agora, como complemento ao anteriormente dito, um dos tema mais polêmicos da bioética nos séculos XX e XXI: a eutanásia, originalmente definida como a boa morte; no grego eu - bom e thanatos - morte. Nos dias de hoje, a isto acrescentou-se mais um sentido: o da indução, ou seja, um apressamento do processo de morrer. 
Só se pode falar em eutanásia se houver um pedido voluntário e explícito do paciente - se este não ocorrer, trata-se de assassinato, mesmo que tenha abranda mento pelo seu caráter piedoso. E é só neste sentido que difere de um homicídio, que ocorre à revelia de qualquer pedido da pessoa.

Horta (1999) traça um histórico sobre eutanásia, apontando que, na sociedade greco-romana, o direito de morrer era reconhecido, como também era permitido que os doentes desesperados pudessem pôr fim a uma vida de sofrimentos; este direito foi interrompido quando a vida passou a ser considerada um dom de Deus. Em 1605, Francis Bacon apontou que a eutanásia passava a ser um assunto médico, tendo a conotação de aliviar o sofrimento de doentes terminais; assim, quando fosse necessário, poder-se-ia apressar a morte. Será que o mais nobre propósito da medicina não seria o de proparcionar uma morte livre da dor e do sofrimento? Neste ponto de vista, a eutanásia e o suicídio assistido podem ser vistos como mortes misericordiosas.

França (1999) discute a polêmica questão do direito de matar e do direito de morrer. Na Grécia, os espartanos jogavam do alto de um monte os recém-nascidos defe ituosos e os idosos; em Atenas, era o Senado que tinha o poder absoluto de decidir sobre a eliminação dos idosos e dos incuráveis. Em Roma, César autorizava o término da agonia de gladiadores feridos, com um movimento dos dedos. Na Índia, as pessoas com doenças incuráveis eram jogadas no Ganges e sua boca e narinas eram vedadas com a lama sagrada. Na Idade Média, os guerreiros feridos mortalmente tinham direito ao punhal, reconhecendo-se seu uso como ato misericordioso, para evitar o sofrimento prolongado. Assim, a eutanásia era admitida na Antigüidade, tanto para eliminação dos imperfeitos, quanto como forma de aliviar o sofrimento, ficando estes dois sentidos misturados durante muito tempo. Já nas práticas de eugenia, no nazismo, há prevalência do primeiro.

Lépargneur (1999) traça a evolução do conceito de eutanásia no século XX. Na Inglaterra, Millard propôs uma legislação sobre eutanásia, em 1931, que deu origem à Voluntary Euthanasy Society. O pastor Charles Potter fundou, em 1938, a Euthanasy Society of America. Mais para o final do século, em virtude das novas técnicas para prolongamento da vida, a que 
foram submetidos Karen Ann Quinlan, Marechal Tito e o General Franco, cientistas premiados com o Nobel se manifestaram a favor de uma eutanásia beneficie nte, para terminar o prolongamento de uma situação que não mais era vida. Atualmente, estas situações já não seriam configuradas como eutanásia, e sim, como medidas de bom senso.

A Declaração sobre Eutanásia, assinada pela Igreja Católica em 1980, entende a eutanásia como uma ação ou omissão de ação que provoca a morte, com o intuito de eliminar a dor e o sofrimento.

Um outro ponto polêmico é o da eutanásia involuntária, ou homicídio, como afirmaram Wooddell e Kaplan (1997-1998), na qual a sociedade procura dar fim à vida da pessoa, por causa do seu sofrimento ou, o que é mais grave, por razões escusas, tais como: economia, disponibilidade de leitos ou eugenia.

Hennezel (2001) inclui uma questão importante para a nossa reflexão, que é a morte roubada, o apressamento da morte sem que haja o pedido explícito do paciente, porque não se agüenta ver o seu sofrimento. Como a autora ressalta, este apressamento pode abreviar o sofrimento, mas também abrevia a possibilidade do contato mais profundo que a proximidade da morte propõe, principalmente no que concerne às despedidas e ao compartilhamento de sentimentos nestas horas. Os hospitais são os locais onde mais se pratica a morte roubada. A autora questiona: não estará a eutanásia se tornando excessivamente rotineira, eliminando-se vidas com muita facilidade? E complementa, afirmando que o fim da vida é tão importante quanto seu início, e não deve ficar à mercê somente das leis.

E aqui se insere a questão da legalização da eutanásia. A autora pondera que esta poderá fazer com que os impulsos mortíferos de alguns profissionais encontrem, aí, um canal fácil de escoamento. Embora, em algumas instâncias, a eutanásia possa parecer uma ação legítima para aliviar tanto sofrimento, sua legalização abre precedentes para a diminuição de cuidados de outra ordem que possam aliviá -lo, sem necessidade de se recorrer à morte. 
Ou seja, será que a legalização da eutanásia não virá em detrimento da criação de programas de cuidados paliativos? A dificuldade de ouvir e compartilhar o sofrimento de outras pessoas pode apressar a morte, sem dar espaço para trocas e despedidas, configurando, assim, a morte roubada. Voltarei à questão legal mais à frente.

A mesma autora tece interessantes reflexões sobre a questão da compaixão e piedade, sendo que esta última se refere à pena, considerando o outro como um ser inferior. Já a compaixão é a possibilidade de sentir junto, sofrer junto. É a possibilidade de permitir que a morte ocorra, mas não significa apressar o processo.

Os pacientes, muitas vezes, pedem que se os acompanhem até o fim da vida, e que não sejam abandonados ou descartados. Como já afirmamos, deixar morrer não significa matar.

Voltando ao aspecto controvertido da eutanásia, é importante salientar que há um intenso debate entre aqueles que são a seu favor e aqueles contrários a ela. Os últimos dizem que é uma "triste sina" para o médico ficar apressando a morte dos seus pacientes, enfatizando os seguintes pontos:

a) $\mathrm{A}$ irrenunciabilidade da vida humana.

b) Considerações de ordem prática, como, por exemplo, mudança de idéia por eventual descoberta de um novo tratamento.

c) Necessidade de discussão sobre a relatividade do que se entende como sofrimento intolerável.

d) Considerações sobre a idoneidade moral e profissional do médico.

Outro ponto a destacar é o de que o conceito de eutanásia passiva trouxe muita confusão para a área, ao ser associado à suspensão de certos tratamentos que promovem o prolongamento da vida, no caso de quadros irreversíveis. Existe uma diferença marcante entre deixar morrer no momento em que a morte é inevitável, e a provocação desta. A idéia de eutanásia passiva vem em conjunto com o que conhecemos como obstinação terapêutica, quando se procura manter a vida, onde a morte já impera. Esta obstina- 
ção, muitas vezes, vem acompanhada de intenso sofrimento, tanto para o paciente, quanto para os seus familiares, configurando o que se denominou de distanásia, prolongamento do processo natural de morrer, do qual falarei mais adiante.

Uma fonte de erro é não distinguir entre a doença aguda, onde tudo deve ser feito, pois há a possibilidade de vida, e a doença terminal, onde a recuperação não é mais possível.

Outra distinção importante a ser feita é sobre tratamentos nos quais a morte é uma consequiência indireta, já que o objetivo principal é o alívio do sofrimento; e, por exemplo, o caso do câncer. Alguns autores definem esta ação como eutanásia indireta; entretanto, este conceito pode causar conf usão e mal entendidos, já que, neste caso, o objetivo principal não é suprimir a vida, mas cuidar da dor e, se a morte ocorre, é um efeito secundário. Por isto é importante utilizar, sempre, o remédio menos drástico em primeiro lugar.

Sob a ótica da qualidade de vida, e não só da vida, a medicina está a serviço da pessoa. Se a vida que é preservada não tem nenhuma qualidade, pergunta-se: será que vale a pena toda uma série de sofrimentos adicionais? Longe de ser simples, esta questão demanda muita discussão. O direito de morrer aponta para a possibilidade de a pessoa poder protestar contra sofrimentos adicionais proporcionados pelos tratamentos que visam a combater a doença, e que acabam por combater a própria pessoa.

Segundo Lépargneur (1999), a vontade de morrer não pode ser excluída de modo absoluto da vida das pessoas. A medicina tem diante de si um desafio ético de humanizar a vida no seu ocaso, devolvendo a dignidade perdida.

Para as pessoas que advogam a legalização da eutanásia, os grandes medos que a justificam são:

- $\quad$ Do sofrimento no momento de morrer: com sufocamento, muita dor e tubos por todo o corpo.

- Da degeneração do corpo, e de que os familiares o vejam assim. 
- $\quad$ Do abandono e solidão na hora da morte.

- Do não respeito ao desejo de morrer.

- Da dependência para as atividades cotidianas.

Foi no seio desse debate que se desenvolveram, na segunda metade do século XX, os grupos Pró Morte com Dignidade, entre os quais um dos mais conhecidos é a Sociedade Hemlock. ${ }^{3}$ Um livro representativo desta época é o de Humphry (1991), Final Exit: The Practicalities of Self Deliverance and Assisted Suicide, ainda sem tradução em nosso meio, e que ficou na lista dos best sellers nos EUA. Vale a pena observar que a palavra deliverance significa parto, ou seja, é uma forma de parto para a morte. Humphry tem outra obra sobre o assunto: Jean's Way: A Love Story, em que conta como realizou o suicídio assistido de sua esposa.

A sociedade Compassion in Dying localiza-se na cidade de Seattle, EUA, e foi fundada em 1993, oferecendo informações, orientação e apoio a familiares e pacientes. Embora a eutanásia e o suicídio assistido não sejam legalizados neste país, estão surgindo as sociedades que propõem a descriminalização destes atos.

Segundo Whiting (1995-1996), o movimento para o direito de morrer tem apresentado um número significativo de adeptos, que procuram autonomia e o direito de decidir sobre a sua própria morte. A Sociedade Hemlock tem 160.000 membros inscritos e, a Sociedade pelo Direito de Morrer, 147.000 (até a data em que este artigo foi publicado). Estes índices devem ser observados com cuidado e debatidos em vários fóruns, envolvendo o público em geral, pacientes, familiares e profissionais de diferentes áreas.

Voltando à questão da legalização, é interessante enfatizar que na Holanda, mesmo sendo o único país onde se pratica a eutanásia legalmente, são tomados muitos cuidados para se garantir a legitimidade do pedido:

3 Hemlock significa cicuta, poderoso veneno usado por Sócrates na hora de sua morte. 
1. O paciente deve reafirmar o pedido várias vezes, ser adulto e estar mentalmente competente.

2. É necessária a presença de dois médicos para garantir a legitimidade do sofrimento e da irreversibilidade do quadro.

3. O paciente deve apresentar dor e sofrimento intoleráveis, tanto do ponto de vista físico quanto psíquico.

4. O médico que está acompanhando o caso deve ouvir a opinião de outro profissional que não o esteja atendendo.

Embora, em princípio, os quatro pontos tenham enunciados claros, podem gerar dúvida, por exemplo: o que é considerado como "mentalmente competente"? Como se pode garantir que um pedido seja de fato voluntário, e não coagido por circunstâncias externas, como a necessidade de liberar um leito ou aliviar o sofrimento da família? O que é, para cada um de nós, sofrimentos intoleráveis? Será que a pessoa não pode mudar o seu ponto de vista?

A eutanásia traz à tona dois princípios que se chocam: por um lado, a autonomia do paciente que quer cuidar de seu próprio processo de morte e, por outro, a sacralidade da vida, postulada pelas pincipais religiões que consideram como transgressão a disposição sobre o próprio corpo.

Pessini e Barchifontaine (1994) fazem importante distinção entre eutanásia e morte com dignidade. O conceito de eutanásia pressupõe tirar a vida do ser humano, envolvendo razões humanitárias para aliviar o sofrimento e a dor, como vimos. A questão de manter, ou não, os aparelhos ligados é mais complicada, pois, embora se trate de quadro irreversível, ainda há vida, e desligá-los, mesmo que para evitar sofrimento adicional, provoca a morte. Estas não são resoluções simples, demandando considerações e reflexões por parte da equipe de saúde.

Wooddell e Kaplan (1997-1998), estudando as atitudes frente à eutanásia e ao suicídio assistido, observaram que, em alguns casos, estes pedidos parecem até muito razoáveis, embora, do ponto de vista legal, a eutanásia seja crime. 
Lachenmeyer et al. (1998) acrescentam alguns pontos para discussão, pela opinião pública, da eutanásia e do suicídio assistido, observando que $60 \%$ dos entrevistados aceitariam a questão do suicídio assistido, para si, se estivessem sofrendo de dor crônica, com doença terminal, perda de mobilidade, perda de independência, ou quando se tornassem uma carga para os outros. Um terço gostaria de morrer se estivesse inc ontinente, ou se tivesse de ir para um asilo. Entretanto, as pessoas com mais idade concordaram menos com a idéia do suicídio assistido. Uma hipótese possível é que a proximidade da possibilidade da morte também aumente o medo do processo de morrer.

Pesquisas mostram que o público, em geral, tem se manifestado favoravelmente à morte com dignidade e à eutanásia. Mudam de atitude por temor à morte, entretanto, como aponta Mishara (1999), quando a pesquisa é feita com pacientes gravemente enfermos.

Schneirdehan (1999-2000) fez um levantamento com profissionais da área de farmácia, que são os responsáveis pelo fornecimento de medicação nos hospitais. Muitos dos remédios usados para alívio da dor e sedação pdem, dependendo de sua dosagem, levar à morte. Eles têm como função principal, assim como todos os profissionais de saúde, proteger e cuidar do paciente. Têm de orientar a equipe quanto aos efeitos colaterais e dosagem dos fármacos, inclusive se forem usados para sedação. E o que é a sedação: busca da morte com dignidade, suicídio assistido ou eutanásia? Como responder? A sedação é uma zona de fronteira entre a eutanásia e um tratamento que pode conduzir ao alívio e controle de sintomas, portanto, favorecendo a qualidade de vida, mesmo que tenha como fator secundário uma abreviação da vida.

Neste caso, os defensores da eutanásia fundamentam seu ponto de vi்ta na incurabilidade de certas doenças, na presença de sofrimento insuportável e citam a questão da morte com dignidade para justificar sua decisão. Neste sentido, o alívio do sofrimento pode ser visto como ato de humanidade e justiça. 
Como no debate sobre a eutanásia há muitas opiniões contrárias, surge um novo conceito, o da criptonásia: uma eutanásia que não é propriamente voluntária, já que não há o pedido do paciente, e sim, uma decisão secreta da equipe médica. Ocorre com mais frequiência com idosos pobres, ou com os mentalmente enfermos. Neste caso, a eutanásia passa a ser uma forma de "matar" os excluídos. Nesta ótica, a legalização da eutanásia aparece como estratégia para matar aqueles que incomodam. É uma eutanásia social, muito semelhante aos procedimentos hitlerianos no holocausto.

A associação de eutanásia com assassinato é muito forte, principalmente em regimes autoritários. Por exemplo, na época do nazismo, eram usados eufemismos para convencer o público da oportunidade do uso dos procedimentos médicos experimentais, com aqueles que se queria eliminar. O filme Dasein ohne Leben (Ser sem vida) apresenta cenas de eliminação de pessoas com problemas mentais, como se este ato fosse um grande benefício para a humanidade. E assim se justifica a eliminação de qualquer pessoa que possa perturbar a ordem vigente: doentes, subversivos e judeus. Eram advogados também problemas econômicos: era permitido matar pessoas para que outras pudessem ter melhor qualidade de vida, como, por exemplo, matar doentes e inválidos para destinar os leitos que ocupavam a outros com maior possibilidade de vida, ou com melhores condições econômicas.

Dizendo de outra forma: com o prolongamento da vida e com o agravamento da doença, os recursos disponíveis diminuem e se tornam muito onerosos, fazendo com que a pessoa se sinta como sobrecarga; nestes casos, o pedido para morrer passa a se tornar razoável e até aceito. Considerar a eutanásia como uma escolha pessoal pode ser uma resposta muito simplista. Deve-se levar em conta que muitos pedidos não são, de fato, verdadeirame nte voluntários, mas, na verdade, são induzidos ou até forçados pela falta de cuidados e recursos adequados.

Entre os eufemismos ligados à eutanásia, Bel Mitchel (1999-2000) arrola os seguintes: assassinato por piedade, morte piedosa, morte com dignidade, final sem sofrimento, término da vida e tratamento humanitário. Todos estes termos trazem a idéia de que há uma atitude humanitária quando se 
considera a eutanásia, mas podem, também, esconder uma intenção malévola de matar. Devem ser considerados, ainda, os termos morte manejada e morte planejada, que traduzem a idéia de que se pode organizar a maneira como a morte vai ocorrer, enfatizando a perspectiva da autonomia. Ilustra esta idéia a palavra alemã para suicídio: Selbstmord (auto-morte) e, também, Selbsttötung (auto-assassinato).

Hennezel (2001) apresenta, em seu livro, o manifesto de 132 pessoas a favor da eutanásí na França, sendo a maioria dos argumentos relacionados ao prolongamento da vida, com sofrimento e indignidade. Um dos pontos debatidos é a dificuldade de envelhecer, visto como uma mancha no narcisismo, ou como a impossibilidade de controle sobre a própr ia vida. O grande medo destas pessoas é o de não ter vida no fim da vida, de estar morta antes de morrer. É uma ferida narcísica e a pessoa questiona: será que poderei ser amada se estiver dependente? A autora rebate a radicalidade destes pontos de vista, perguntando se a dependência não pode ser vivida de outra forma, isto é, associada à solidariedade. Como cuidamos, também podemos ser cuidados um dia.

A autora cita o livro de Albom (1997) A Última Grande Lição: O Sentido da Vida, que relata a experiência de como o professor-protagonista viveu os últimos dias de sua vida, dependente de outras pessoas para todas as atividades cotidianas, e como achava importante compartilhar esta experiência com seu exaluno e amigo jornalista, que transformou esses momentos em livro - que poderá ser base de reflexão para pessoas que estão vivendo seus processos de morte. Na obra, constam as conversas entre o autor e Morris, seu professor, e, em cada $3^{\text {a }}$ feira (dia dos encontros e seu título original), um tema era debatido. Este livro, que aborda diretamente o processo de morrer, em todas as suas facetas, algumas bastante impactantes, ficou várias semanas entre os best-sellers - mais um paradoxo destes tempos de morte interdita. 


\section{Eutanásia sob o ponto de vista religioso}

As religiões têm um papel muito importante para a humanidade, principalmente quando o sofrimento e a dor se fazem presentes, oferecendo acolhida e reflexão nestes momentos, orientando para uma vida responsável, garantindo uma vida plena de felicidades. De uma for ma ou de outra, todas estão relacionadas com o sentido da vida, liberdade, justiça e direcionamento da consciência.

Com exceção do budismo, que considera a vida como um bem precìso, mas não de âmbito divino, em todas as outras religiões ela é vista como sagrada. Em relação às discussões atuais sobre a preservação da vida e o avanço tecnológico, as principais religiões se posicionam pela primeira até seu fim natural, manifestando-se a favor do cuidado aos pacientes com doença avançada, devendo se preservar a dignidade no adeus à vida, evitandose o prolongamento artificial e penoso do processo de morrer.

As religiões buscam, também, uma ética de responsabilidade, discutindo as consequiências de certas ações, e também de certas omissões. É aí que cabe a discussão sobre eutanásia. Pessini (1999) traça um painel sobre as diversas religiões, e como seria seu posicionamento diante da questão do apressamento da morte - eutanásia ou suicídio. Seguemse, pois, as peculiaridades de algumas das principais religiões, atualmente professadas, tal como expostas pelo autor.

\section{Budismo}

No Budismo, não há uma autoridade central, sendo objetivo de todos budistas a iluminação e, assim como o próprio Buda buscou o seu caminho, cada pessoa pode traçar o seu. É uma filosofia de vida, o caminho da sabedoria. A vida é transitória e a morte inevitável, e é importante deixar que siga seu transcurso natural. Além disso, a morte perturba o processo dos sobreviventes e não deve ser prolongada indefinidamente quando não houver possibilidade de recuperação, mas, também, não deve ser apressada. O 
momento da morte é fundamental (como se lê no Bardo Thodol - O Livro Tibetano dos Mortos, apresentado ao mundo ocidental por Ewans- Wentz, em 1960), pois o que governa o renascimento é a consciência e a aprendizagem na hora da morte; por isto, é importante ter pensamentos apropriados neste momento.

Há uma restrição no que concerne aos transplantes, uma vez que a unidade corpo e espírito continua após a morte. Remover um órgão do cadáver é uma perturbação đsta unidade; pelo mesmo motivo, autópsias também são contra-indicadas.

Como a morte é uma transição, o suicídio não pode ser visto como escape, portanto, é condenado. Alguns suicidas foram perdoados por Buda, quando este percebia que não eram atos egoístas, movidos pelos desejos, mas sim, guiados pelo caminho da iluminação. Há um reconhecimento da sabedoria das pessoas na determinação do fim desta existência e a passagem para a seguinte. É importante considerar o momento da morte e a maneira como vai ocorrer, a sua dignidade.

Devemos lembrar que a lei japonesa não incentiva o suicídio, e penaliza aqueles que ajudam os outros a executá-lo. Entretanto, se no processo de morrer houver sofrimento intolerável, é permitido o auxílio, é o que se vê no hara kiri quando o samurai, rasgando seu abdômen, tem um auxiliar que o degola, porque o sofrimento é muito grande e demorado com o corte abdominal. É importante que a tensão seja diminuída, para que se possa ter paz mental.

As drogas usadas para aliviar a dor são permitidas, mesmo que possam matar o paciente. Entretanto, é necessário verificar se é o caso de administrá-las, garantindo o máximo possível de lucidez do paciente no momento de sua morte. Por isto, na visão budista, é um absurdo manter o paciente inconsciente, vivo, quando não há possibilidade de recuperação. Na tradição budista, valoriza-se muito a decisão pessoal sobre o tempo e a forma da morte. Todos os atos que dificultem esta decisão, ou que nublem a consciência da pessoa, são condenados. A vida não é divina e, sim, do homem, e a preocupação é com a evolução da pessoa, a lei do Karma. 


\section{Islamismo}

Islamismo significa, literalmente, submissão a Deus. A vida humana é sagrada e tudo deve ser feito para protegê-la; o mesmo vale para o corpo, que não deve ser mutilado em vida ou depois da morte. É importante lavá-lo e envolvê-lo em pano próprio, orar e depois enterrá-lo.

Deus é a suprema força que governa os homens, portanto, o suicídio é considerado como transgressão. O médico é um instrumento de Deus para salvar pessoas, não pode tirar a vida de ninguém, nem mesmo por compaixão; mas também não deve prolongá-la a todo custo, principalmente quando a morte já tomou conta. Os islâmicos são totalmente contrários aos transplantes, porque provocam mutilação no corpo.

\section{Judaísmo}

A grande questão para o judaísmo é definir o momento da morte, término da vida. A morte encefálica é o determinante do momento da morte. Mas, para alguns mais tradicionalistas, o critério válido de morte é a parada cardíaca e respiratória.

Sobre a eutanásia, os rabinos de várias linhagens têm opiniões coincidentes. A morte não deve ser apressada e o moribundo deve receber os tratamentos dos quais necessita. A decisão sobre a própria morte não cabe ao sujeito, e sim aos rabinos que, ao interpretar a Torah, aplicam seus conhec imentos à vida cotidiana. Mesmo não sendo a cura não é possível, não se deve deixar de cuidar, e a pessoa não deve ser deixada sozinha quando est $\mathrm{i}$ ver morrendo. O médico é um servo de Deus para cuidar da vida humana e não deve apressar a morte. O que deve ser preservado é a vida e não a agonia.

\section{Cristianismo}

A "Declaração sobre a Eutanásia", de 5 de maio de 1980, da Sagrada Congregação para a Doutrina da Fé, é o documento mais completo sobre o 
assunto nesta religião. A eutanásia é condenada como violação da lei de Deus, ofensa à dignidade humana e um crime contra a vida. Entretanto, isto não quer dizer que se tenha de preservá-la a todo custo, prolongando a agonia e o sofrimento. O conflito sobre o que seriam tratamentos ordinários e extraordinários ainda continua, assim como uma grande preocupação com o sofrimento durante o processo da morte, e com a velhice indigna. Não é considerada eutanásia a interrupção de um tratamento, que não oferece cura ou recuperação, e, sobretudo, causa muita dor e sofrimento. Deixar morrer não significa matar. Esta última ação é que é vedada.

Observando os postulados dos credos religiosos apresentados, a eutanásia é uma transgressão e, também, assunto fértil para controvérsias, conflitos e discussões. O foco é o questionamento sobre a autoridade divina e a possibilidade de auto-determinação do ser humano e por isto o diálogo entre ética e religião é fundamental. A vida não é só biológica, mas também biográfica, incluindo: estilo de vida, valores, crenças e opções.

\section{Eutanásia e a questão legal - mais algumas implicações}

O debate sobre a legalização da eutanásia está cada vez mais presente, principalmente depois que a Holanda se tornou o único país a legalizar o ato de apressar a morte. Todavia, se, por um lado, há grande pressão para essa legalização, por outro existe o movimento contrário, igualmente forte, pelo temor de que seja praticada sem limites; este temor é tal que, na própria Holanda, foi criada uma "Associação de Proteção à Eutanásia".

A discussão sobre a legalização da eutanásia é trazida à baila quando são cometidos abusos terapêuticos como, por exemplo, manter a todo custo uma vida que está se finalizando. É sempre importante a escuta e a acolhida de alguém que quer encerrar sua vida com dignidade. Por outro lado, existe o temor de que a morte será apressada de modo muito fácil com os chamados excluídos: pobres, idosos, deficientes e psicóticos - como já foi comentado. 
Dodge (1999) aponta que o pedido para descriminar a eutanásia e o suicídio assistido aparece quando se vêem casos extremos, em que tanto a manutenção acirrada da vida, como o apressamento da morte, trazem o conflito à tona. Para o autor, o argumento principal para a legalização de eutanásia é o princípio da autonomia: as pessoas tê $m$ direito moral de tomar decisões a respeito de suas próprias vidas e a lei deveria respeitar este direito.

Entretanto, a própria idéia de autonomia pode ter contornos polêmicos, quando se pensa na possibilidade de se fazer o que se quer: até onde se pode ir, quando se ferem os direitos de outros? Quando o tema é abordado, estamos perante uma pluralidade de pontos de vista. No que se refere a direitos humanos e, mais particularmente, quando está em jogo a vida e a morte, é fundamental considerar que são os membros da sociedade que devem ser protegidos, e não o desejo dos poderosos.

A ligação da morte com dignidade e a permissão para matar é complicada e pode representar risco para aqueles que são, de alguma forma, vulneráveis. A ligação da eutanásia com doença terminal não é obrigatória; primeiro, porque o assunto não é só pensado para estes pacientes e, segundo, porque a eutanásia não é o único procedimento que resta para pacientes gravemente enfermos. Então, a questão de ser ou não um doente em estágio terminal não é o ponto essencial na discussão sobre eutanásia e sua legalização.

Outro aspecto a ser considerado é o que define um sofrimento como insuportável, e quem assim o define: o paciente ou a equipe? Pode-se dizer que um pedido é justificado e outro nã o? São perguntas complexas que demandam discussões multidisciplinares.

Mais uma questão a ser levantada é que a legalização da eutanásia pode levar a erro, abuso e desgaste da relação médica. Cada vez mais é necessário desenvolver o que se chama de diretrizes futuras, os testamentos de vida e os poderes legais, como já mencionamos; todos estes são instrumentos jurídicos, que podem ser usados para decisões subrogadas, quando a pessoa não pode mais falar de si e por si. 
No Direito Brasileiro, a eutanásia é vista como homicídio, portanto, ilícita e imputável, mesmo que a pedido do paciente (Artigo 66/1988). A morte termina a existência de uma pessoa e, com isto, cessam seus direitos; mas o paciente terminal, mesmo que em agonia, mantém a personalidade jurídica, pois ainda vive. Há um grande paradoxo sobre o fim da vida, e o Código Civil Brasileiro fala em liberdade e dignidade, mas esta liberdade não inclui a disponibilidade da própria vida, como aponta Martin (1993), que realiza uma leitura ético-teológica da relação médico-paciente terminal nos códigos brasileiros de ética médica.

Uma das conclusões importantes desse autor é a riqueza de aspectos apresentada sobre o tema nos códigos brasileiros, com um forte cunho humanitário de tradição secular, cujo valor central é a pessoa humana, com a ênfase na benignidade e que muitos profissionais desconhecem. A esta tendência se contrapõe uma ética mercantilista, preocupada com a economia, que vê a medicina como um negócio como outro qualquer.

E, talvez por isso, aumentaram os pedidos para legalização da eutanúsia, relacionados também com a necessidade de "racionamento" da assistência médica por falta de recursos.

Se, em 1984, há uma predominância do medicocentrismo e uma busca, nos aspectos legais, da decisão para os seus atos, perdendo-se um pouco o valor do humano, já, em 1988, retomam-se como eixo os direitos do paciente terminal, o direito à verdade e o direito de participar das decisões sobre a própria vida.

Dodge (1999) também apresenta um histórico dos códigos criminais no Brasil, em relação ao tema da eutanásia. No código de 1830 nada constava sobre eutanásia, mas havia referências ao suicídio assistido, imputando-se pena de dois anos de prisão e, em 1890, é previsto um aumento desta pena. No Código vigente, a euta násia é vista como assassinato, e o motivo piedoso alegado não atenua a pena.

Entretanto, o médico será obrigado a prolongar a vida se este for o desejo explícito do paciente ou de seus familiares. Portanto, a distanásia não é imputável, mesmo se comprovado que causa muito sofrimento, a não ser 
que as intervenções utilizadas para prolongar a vida possam ser caracterizadas como a razão para seu encurtamento.

Infelizmente, não se pode condenar o médico quando este realiza tratamentos fúteis, infligindo grande sofrimento aos seus pacientes. O consenso, nestes assuntos, é muito difícil de ser alcançado.

A ortotanásia, entendida como possibilidade de suspensão de meios artificiais para manutenção da vida quando esta não é mais possível (desligamento de aparelhos quando o tratamento é fútil, não promovendo recuperação e causando sofrimento adicional), não é um ato ilícito. Ou seja, a conduta de desligar equipamentos será lícita se não significar encurtamento da vida, obedecendo ao princípio de não maleficência.

\section{Definição do momento da morte e suas implicações}

No meio desta polêmica sobre a abreviação ou prolongamento do processo de morrer, cabe uma questão importante: a definição do momento da morte. Lamb (2001) descreve os aspectos envolvendo a trajetória e as definições sobre a morte encefálica - atualmente condição necessária e suficiente para se atestar a morte, já que define um ponto sem retorno no processo de morrer, no qual a perda de integração do corpo é definitiva.

A morte encefálica é a ausência total das funções cerebrais, coma irreversível, apnéia e reflexos e, neste caso, a Lei 9434, de 1997, em território nacional, permite a retirada de órgãos, tecidos e partes do corpo humano.

A definição de morte encefálica tem sua origem na França a partir do conceito de coma depassé, um estado além do coma, descrito nos trabalhos de Mollaré e Goulon (1959) e citados por Lamb (2001), que o definiram como um estado de irresponsividade, flacidez, dificuldade de regulação térmica, ausência de reflexos e falta de respiração autônoma. Como este termo chegou a gerar confusão com os outros estágios do coma, passou-se a utilizar o termo "morte encefálica" em vez de coma, para evitar qualquer ambigüidade. Esta definição passou a ser fundamental devido ao avanço tecnoló- 
gico da medicina e às inúmeras intervenções para adiar e prolongar o processo de morrer.

Este autor, ao traçar um histórico a respeito dos critérios para definição da morte, lembra que religiões e culturas tinham as mais variadas concepções sobre a morte, antes de serem definidos os critérios médicos. Os egípcios consideravam o coração como o órgão vital mais importante, e os judeus atribuíam à respiração independente e aos batimentos cardíacos os elementos essenciais para se considerar a vida. Os cristãos acreditavam que a alma estava na cabeça, por isto, o critério cerebral pode ser adequado. No pensamento japonês, o abdômen e as vísceras são considerados o elemento chave para a vida, daí a origem do hara kiri, no qual a espada é enfiada nesta região e não no coração. Por toda esta diversidade de órgãos essenciais, pode-se imaginar que não é fácil a aceitação do critério encefálico como o único para a definição da morte.

No histórico das definições da morte, esta foi considerada como o último sopro de vida. Ainda no século XVIII a putrefação dos corpos era o sinal manifesto de que a morte havia, de fato, ocorrido. Os velórios, nesta época, além de serem rituais de despedida, permitiam o tempo necessário para comprovar que a morte havia ocorrido, e de que não se enterraria uma pessoa viva. Com a descoberta da circulação sangüínea e do estetoscópio, o critério da morte passa a ser a ausência dos batimentos cardíacos.

O autor aponta, como fato interessante, que os escritos de Descartes afirmavam que o ser vivo era uma máquina, e na divisão que propunha, os médicos cuidavam da mecânica e, os padres, do espírito.

Do ponto de vista biológico, a morte pode ser vista como um processo que se inicia quando um órgão vital cessa seu funcionamento, e acaba quando todo o organismo se decompõe. A moral e a lei exigem que a morte seja tratada como evento no qual a impossibilidade de organização e integração das funções do corpo leva a uma perda do que é essencial e significativo de forma irreversível; ou seja, há impossibilidade de regeneração. Quando se chega a este estado, não vale a pena nenhuma intervenção ou substituição de órgãos. O Papa Pio XII, grande autoridade religiosa do século XX, se pro- 
nunciou a respeito da questão, afirmando que o prolongamento da vida é uma questão médica e não religiosa, e que critérios razoáveis devem ser aplicados neste caso.

Lamb (2001) enfatiza a necessidade de discussão sobre a diferença entre os termos morte encefálica, que representa o fim da coordenação da vida vegetativa e da vida de relação, e morte cerebral ou cortical, que significa o fim da vida de relação. A morte não é um evento instantâneo, na maior parte das vezes, e sim, uma sequiência de fenômenos que ocorrem gradativamente nos vários órgãos do corpo.

Do ponto de vista psicossocial, pode-se falar na morte em vários ńveis: físico, psicológico ou social; entretanto, o critério de morte, tem de ser único e preciso. Segundo o autor, é necessário que se faça uma diferenciação entre definições possíveis e critérios. A definição pode ter vários contornos, como já vimos, mas os critérios têm de ser objetivos. Portanto, morte encefálica não é um conceito novo e sim, um critério. $\mathrm{O}$ encéfalo é um órgão crítico para o que chamamos de vida, e que não pode ser substituído; neste caso, ño importa que outros sistemas estejam funcionando por meios artif iciais, pois sabe-se que, após a morte encefálica, os outros sistemas, como o circulatório e respiratório, cessam também, após algumas horas ou dias.

A definição do momento de morte, além de garantir os rituais fúnbres a quem de fato morreu, se reveste de grande importância para se estabelecer o momento de retirada de órgãos para fins de transplante. O grande desenvolvimento das técnicas de reanimação, a partir da década de 1960, traz à tona a questão sobre quais são os casos que devem ser submetidos a elas. O desenvolvimento da respiração artificial, em 1976, permite a reanimação, menos artesanal do que os sais aromáticos usados para os desmaios nos tempos antigos e, mais recentemente, os choques cardíacos.

Para se determinar a morte encefálica é necessário excluir aquelas situações que apresentam características semelhantes, como é o caso de hipotermia e intoxicação por drogas. A grande diferença é que, nestas últimas situações, pode haver uma reversão dos quadros e, no caso da morte encefálica, a irreversibilidade é total. Daí a necessidade de se esperar pelo menos 
72 horas para concluir o diagnóstico, e não apressar a morte, mesmo que seja para fins de transplante. O problema é que os instrumentos para avaliar a morte encefálica ainda não são tão precisos. $\mathrm{O}$ eletroencefalograma, um dos exames clássicos, apresenta distorções, pois é sabido que algumas pessoas com traçado isoelétrico se recuperaram. Outro exame que também é utilizado é a angiografia; é um procedimento extremamente invasivo, que pode causar danos adicionais. Então, o dilema se coloca: é válido realizar um exame para se saber se ocorreu morte encefálica, e aí poder causar uma lesão que pode ser o motivo da morte?

O parecer n ${ }^{\circ} 12 / 98$ do Código de Ética Médica se refere à morte encefálica como o momento do óbito, e a família precisa ser avisada antes do desligamento dos aparelhos ou da não reanimação. É importante, também, informar a equipe de enfermagem, que é a que está mais em contato com o paciente e seus familiares. Como a morte encefálica é considerada, na maior parte dos países ocidentais, como sinônimo de óbito, só após sua ocorrência se passa a manipular o corpo cadáver, em caso do uso de órgãos para transplante. Se for constatada morte encefálica, o prolongamento dos tratamentos pode configurar obstinação terapêutica, como já apontado.

Assim, do ponto de vista ético, não se justifica o apressamento da morte, mesmo que seja para fins de transplante; o argumento de que uma vida pode ser salva não permite que se disponha de uma que ainda está presente. Vemos que a compreensão sobre vida e morte no caso da morte encefálica é complexa, embora os critérios estejam definidos. Podemos observar esta ambigüidade, quando os médicos pensam em anestesiar os pacientes com morte encefálica, ao retirar os órgãos, para que não sintam dor. O reconhecimento da morte encefálica afirma que o paciente está morto, e não que está para morrer e que ainda pode se recuperar.

França (1999) apresenta uma questão interessante: não cabe matar quem está vivo, nem manter vivo quem está morto, não há meia vida nem meia morte.

De qualquer forma, o conceito de morte encefálica deve ser mais bem explicitado para a sociedade, a fim de que esta possa se tornar co-partícipe 
na discussão. Ao se definir melhor o conceito de morte e de morte encefálica, cai por terra o conceito de eutanásia passiva. O esclarecimento sobre o que constitui distanásia também é importante, porque o prolongamento da vida, a todo custo, é absolutamente inútil.

Finalizando, pode-se enfatizar que muitos debates sobre eutanásia acabam por promover uma polêmica entre o tudo ou nada, levando a conclusões simplistas em questões que demandam demorada reflexão, até que todos os pontos de vista sejam considerados.

\section{Suicídio assistido}

O que diferencia a eutanásia do suicídio assistido é quem realiza o ato; no caso da eutanásia, o pedido é feito para que alguém execute a ação que vai levar à morte; no suicídio assistido é o próprio paciente que realiza o ato, embora necessite de ajuda para realizá-lo, e nisto difere do suicídio, em que esta ajuda não é solicitada.

A seguir, explicitarei melhor o que entendo por suicídio assistido. $\mathrm{Ca}$ be lembrar que, às vezes, a diferença entre eutanásia e suicídio assistido não fica muito clara, o que dificulta a realização de pesquisas sobre o assunto.

O contexto cultural da morte planejada envolve importantes significados sociais. Historicamente, o suicídio teve conotações diferentes. Na Grécia, os estóicos viam o suicídio como um ato racional, alternativa para uma vida em desarmonia. Os romanos consideravam que se podia preparar a própria morte, principalmente quando a vida era indigna; os únicos que não podiam assim pensar eram os escravos, porque não eram considerados como seres humanos e, sim, como mercadoria e, portanto, sua morte envolveria perdas financeiras. Do ponto de vista cristão, pode se olhar a questão do suicídio por dois ângulos: a possibilidade de elevação da alma, através do martírio, o que é aceito e até louvado; entretanto, o homem não tem direito de dispor da própria vida, desafiando Deus. 
O suicídio já foi visto como crime e, portanto, passível de punição, ou seja, se a morte não ocorresse, a pessoa era condenada à pena máxima.

$\mathrm{Na}$ atualidade, a psicanálise, a partir dos estudos sobre a dinâmica psíquica, encaminha a questão para o âmbito subjetivo, ligando o suicídio à doença mental.

No século XX, a partir da mentalidade da morte interdita e vista como fracasso, e com o prolongamento da vida a todo custo, surgem vários movimentos que discutem a dignidade no processo de morrer. É no seio deste movimento que começa a germinar, como um dos seus focos, o suicídio assistido. O termo suicídio assistido apareceu em 1990, envolvendo Jack Kervokian, médico do estado de Oregon, que relata o caso de sua paciente Janet Atkins, portadora da doença de Alzheimer. O suicídio assistido, neste caso, foi proposto como uma forma de driblar a solidão que ela sentia. No geral, a proposta de Kerkovian sustenta que o suicídio assistido é uma forma de morte planejada, como possibilidade de se assumir tanto a vida como a própria morte com dignidade.

Kervokian desenvolveu o mercitron, uma máquina que provoca suicídios "piedosos" (merciful), segundo suas pahvras. A máquina tem três seringas e uma agulha com um dispositivo para ser acionado; na primeira seringa existe uma solução salina, cuja função é deixar uma veia aberta; na segunda, um poderoso relaxante muscular, que pode ser manipulado pelo paciente, quando este quiser iniciar o processo; e na terceira, cloridato de potássio, que provoca parada cardíaca imediata. Quando o paciente aciona a segunda seringa, imediatamente inicia o processo de sua morte. Este é o exemplo clássico de suicídio assistido porque, de alguma forma, implica na vontade e ação do paciente, configurando o que Kervokian chama de medicídio, a morte planejada.

Nos Estados Unidos, o movimento do suicídio assistido adquire grande força, já que, neste país, a autonomia e a individualidade são consideradas grandes valores. Kervokian propõe alívio da dor, do sofrimento e diminuição dos custos na hora da morte. É uma forma de planejar e administrar a 
morte. Os obitaristas, ou administradores da morte, serão os responsáveis por esta tarefa.

Markson (1995) refere-se a esse médico, conhecido como o Dr. Morte, que auxiliou 92 pessoas no processo de morte, e foi condenado a 25 anos de prisão por assassinato e uso de substâncias proibidas. Kervokian escreveu, em 1991, uma obra chamada Medicide, na qual expõe suas idéias principais.

O Omega, Journal of Death and Dying, dedica o volume 40 (19992000) à discussão sobre Kervokian, apresentando a opinião de eminentes tanatologistas sobre o assunto.

Kastenbaum (1999-2000), o eminente tanatólogo americano, tece suas considerações sobre esse médico, situando-o na história das mentalidades sobre a morte, no final do século XX. Refere-se à sua origem como patologista, e sua preocupação com o momento da morte, tendo posteriormente se envolvido com a questão de doação de órgãos de prisioneiros condenados. Considera que Kervokian acabou se tornando mais conhecido pelo seu sensacionalismo, do que pela contribuição que pudesse ter dado à área da tanatologia. Lembra, também, que o médico não se vinculou ao movimento hospice, que se preocupa fundamentalmente com a dignidade no processo de morrer. $\mathrm{O}$ autor faz um mea culpa ao analisar o colega, afirmando que no movimento dos deathnicks, como denomina os tanatólogos, houve preocupação muito maior com a questão do luto e com o detalhamento de variáveis em inúmeras pesquisas, do que com o processo da morte. Considera que Kervokian pode ter se apropriado deste espaço, já que inúmeras pessoas se preocupam muito com a sua própria morte, e com o processo de morrer, porque acreditam que ocorrerá com sofrimento intolerável.

Canetto e Hollenshead (1999) realizaram um estudo que analisou 47 casos atendidos por Kervokian, entre os anos de 1990 e 1997, dos quais 68\% eram mulheres; $31 \%$ estavam em estágio terminal da doença; $74 \%$ tinham dor e, apenas 42,6\% destes, tinham uma explicação orgânica para seu quadro, muitos tinham dor intolerável e, pior ainda, sofriam sem saber a causa, sendo acusados de estar fingindo ou inventando; 36\% tinham depressão; 
$66 \%$ grandes deficiências e $90 \%$ estavam totalmente dependentes, corroborando o fato de que, mais do que o medo da morte, está presente um grande temor de se sentir dependente e à mercê de outra pessoa. Do total dos casos, $47 \%$ eram portadores de câncer e uma porcentagem significativa tinha esclerose múltipla.. $\mathrm{O}$ autor considera importante observar o porquê de uma porcentagem maior de mulheres pedir ajuda para o suicídio, e sugere que seria pelo fato de viverem por mais tempo e, por isto, sofrerem mais com doenças crônicas, incapacitantes. Estas mulhe res têm menos apoio da família, muitas vezes não presente, já que seus esposos morreram; estavam sós e várias delas institucionalizadas.

Kaplan e Bratman (1999-2000) atualizaram o estudo anterior, incluindo 75 casos, com as mesmas tendências. É importante considerar que Kervokian foi sempre muito favorável a expor seus casos na mídia, como forma de ampliar a militância na questão da morte com dignidade e pelo direito à morte. Estes autores discutem sobre quem ele é: um visionário, um serial killer ou um mártir. Em 1998, o médico ofereceu à rede de TV americana CBS a realização do processo de eutanásia ao vivo, o que obviamente não foi aceito. Mesmo assim, participou do programa, e afirmou que, se fosse preso, faria greve de fome.

A discussão proposta é: dependendo da interpretação que se faça dos seus atos, ele pode aparecer como alguém que se preocupa com a qualidade de vida, autonomia de pessoas em intenso sofrimento, advogando a dignidade no processo de morrer. Porém, com a necessidade de aparecer e criar polêmica, pode estar fazendo um desserviço para o movimento pró morte com dignidade. Muitos o vêem como assassino, e concordam com a sua prisão.

Segundo Gutman (1999-2000), o que assusta no caso Kervokian não é seu empenho em tentar ajudar os pacientes a terem uma morte digna, e sim, o fato de poder estar usufruindo prazer deste ato, mantendo-se sempre na berlinda. $\mathrm{O}$ autor traça um paralelo com os xamãs, grandes curadores, que, por isto, se tornavam muito poderosos; esta sensação de poder tende a cegar a racionalidade e a humildade frente à vida e à morte. 
Segundo Kaplan e Bratman (1999-2000), a eutanásia é ilegal nos Estados Unidos, mas o suicídio assistido foi legalizado nos estados de Oregon e Michigan, este último terra de Kervokian. Como a diferença entre suicídio assistido e eutanásia nem sempre é muito clara, a confusão permanece.

Um dos pontos mais temidos no processo de morrer, na atualidade, é a incerteza, isto é, saber que a morte virá, mas não saber quando nem como, sem controle ou planejamento. Aí a eutanásia e o suicídio assistido podem surgir como possibilidades para este planejamento.

\section{Distanásia}

A manutenção dos tratamentos invasivos em pacientes sem possibilidade de recuperação é considerada distanásia, obrigando as pessoas a processos de morte lenta, ansiosa e sofrida, sendo sua suspensão uma questão de bom senso e racionalidade.

Melhor definindo, distanásia é morte lenta, ansiosa e com muito sofrimento. Trata-se de um neologismo composto do prefixo grego dys, que significa ato defeituoso, e thanatos, morte. Trata-se de morte defeituosa, com aumento de sofrimento e agonia. É conhecida também como obstinação terapêutica e futilidade médica.

A distanásia é sempre o resultado de uma determinada ação ou intervenção médica que, ao negar a dime nsão da mortalidade humana, acaba absolutizando a dimensão biológica do ser humano.

Entre pessoas famosas que passaram por esta situação podem ser citados: Truman, Hiroíto, Franco e, no Brasil, Tancredo Neves.

O maior risco da distanásia ocorre em instituçõos de saúde muito bem aparelhadas, com instrumentos cada vez mais sofisticados para o ressuscitamento, trazendo a questão: até quando a vida deve ser prolongada, e a quem cabe tal decisão?

Associada à distanásia, surge a questão sobre o que são tratamentos fúteis. A futilidade foi definida pelo Hastings Center, que estabeleceu as 
diretrizes nesta área, e que fez publicar o documento Guidelines on the Termination of Life Sustaining Treatment and the Care of the Dying (Hastings Center, 1987). O termo fútil se origina da palavra futilis, que significa furado. Os tratamento fúteis são entendidos como aqueles que não conseguem manter ou restaurar a vida, garantir o bem estar, trazer à consciência, aliviar o sofrimento; ao contrário, só levam a sofrimentos adic ionais. A grande dificuldade é determinar o que são tratamentos ordinários, obrigatórios para salvar o paciente, ou oferecer alívio e controle de seus sintomas; e quais são extraordinários, também conhecidos como fúteis. Surge, então, um novo conceito, que é o do tratamento proporcional para cada caso, ou seja, eficaz para cuidar daquilo a que se propõe.

Pessini (2001b) escreveu sua tese de doutorado sobre a distanásia, relacionando-a com as principais questões da bioética. Intitulada Viver com Dignidade a Própria Morte: Reexame das Contribuições da Ética Teológica no Atual Debate Sobre Distanásia, foi publicada, no mesmo ano, em livro: Distanásia: Até Quando Prolongar a Vida? (Pessini, 2001a). São obras de leitura obrigatória para aqueles que se debruçam sobre os temas do prolongamento da vida, distanásia, tratamentos fúteis e ortotanásia.

Pessini foi capelão do Hospital das Clínicas da FMUSP, de 1983 a 1995, e teve contato muito grande com pacientes internados, muitos deles em estágio terminal da doença, vivendo a dor e o sofrimento que a aproximação da morte provoca. Atualmente, é o dirigente do Centro Universitário São Camilo, responsável por vários cursos na área de saúde e teologia, e um dos mais conhecidos bioeticistas em nosso meio.

Segundo o autor, a questão da distanásia surge num contexto da medicina e da tecnociência que, diante de uma doença incurável, transforma em obsessão a "cura da morte", como se isto fosse possível, negando-se a dimensão de finitude da humanidade. Cabe ressaltar, no entanto, que a crítica ao tratamento fútil não significa matar o paciente, nem abandoná-lo à própria sorte.

Alguns países propuseram diretrizes sobre como definir a irreversibilidade dos quadros, medidas cabíveis e o prolongamento ou não da vida, e 
Pessini (2001a, 2001b) cita-os em seu trabalho. As dificuldades maiores estão relacionadas com alguns profissionais de saúde, que não conseguem reconhecer que a morte é irreversível, que não há mais sentido em manter tratamentos que só prolongam funções fisiológicas. Além disto, muitos deles têm dificuldades de comunicarem este fato à família.

A pergunta que se coloca é: o que deve predominar na decisão sobre os tratamentos, a sacralidade ou a qualidade de vida? Pergunto, então, sobre a diferença entre a vida biológica e biográfica. Pessoas podem estar vivas e não ter vida. Ou seja, o coração pode estar batendo, e a pessoa estar totalmente inconsciente, sem possibilidade de contato.

Também é importante considerar que há diferenças entre matar e deixar morrer. Quando uma pessoa não tem mais vida, estando apenas algumas funções vitais preservadas, interromper os tratamentos não é eutanásia.

Quando se analisa a questão de pacientes em estágio terminal da doença, é importante considerar que existem vários níveis de gravidade. Há pacientes com doença avançada, que podem se beneficiar de tratamentos, mesmo que sejam invasivos e dolorosos, porque há possibilidade de melhorar sua qualidade de vida. Em outros casos, nenhuma recuperação é possível, e estes mesmos tratamentos passam a representar um sofrimento inútil. É neste caso que se faz necessária a reflexão sobre sua continuidade, configurando a distanásia. Ou seja, o mesmo procedimento pode ser a conduta indicada, ou o prolongamento de um sofrimento inútil.

Uma outra questão polêmica, já mencionada, é a diferença entre o que se considera como tratamento ordinário ou extraordinário. Uma traqueotomia para facilitar a respiração pode ser considerada como tratamento ordinário para um paciente com doença irreversível. Submeter este mesmo paciente à hemodiálise pode ser considerada medida extraordinária, uma vez que só prolonga a vida, sem perspectiva de melhora.

O temor que surge, a partir dessas questões, é que alguns procedimentos, como cuidados com alimentação, higiene, alívio da dor etc., podem deixar de ser usuais para garantia da qualidade de vida e se tornarem procedimentos extraordinários no caso de pacientes em estágio avançado. Como já 
exaustivamente defendido, cuidados constantes, discussões com familiares e pacientes, sempre devem fazer parte dos procedimentos no caso do agravamento da doença. Todas estas questões se complicam, ainda mais, quando o paciente é uma criança.

O conceito de futilidade médica leva em conta somente a duração da vida, e não sua qualidade, como já vimos. Ou seja, há casos em que o prolongamento da vida só causa sofrimento. Por exemplo, nos casos de máformação grave, nos quais só há perspectiva de vida vegetativa, com alto risco de morte, fica a pergunta: quanto investir e quando parar? Pacientes em estágio vegetativo não apresentam possibilidade de recuperação, não têm evidência de consciência, não manifestam comportamentos voluntários, não têm compreensão ou expressão verbal, apresentam estado de acordar intermitente, sem as mínimas condições de sobrevivência, mesmo que apresentem alguns reflexos. Muitos destes quadros são ligados a lesões graves do sistema nervoso central e a síndromes degenerativas e metabólicas.

Em pesquisa realizada com médicos sobre como e quando retirar o suporte vital, os pontos considerados foram: a) qualidade de vida do pacie nte, b) possibilidade de sobreviver ao tratamento; c) natureza da doença e sua reversibilidade.

Kipper (1999) discute que, com todos os problemas econômicos do Brasil, ainda se mantêm os pacientes em estado terminal por muito tempo nas UTIs, porque os profissionais de saúde temem as conseqüências do desligamento dos aparelhos, e se sentem sozinhos nestes momentos. A família precisa ser informada, e ter tempo para elaborar o que significa este desligamento de aparelhos.

Mota (1999) comenta que, às vezes, os tratamento fúteis são propostos porque é difícil assistir à pessoa durante seu processo de morte. O paciente pode ser colocado no respirador porque é muito angustiante ver suas dificuldades respiratórias. Não se percebe o limite entre o que é razoável e a obstinação terapêutica, quando o que se proporciona são apenas sofrimentos.

Quando se discute o que é vida, devemos lembrar que a medicina não tem como único objetivo manter índices fisiológicos, como o pulsar de um 
órgão, e sim cuidar de uma pessoa. A escolha de determinado procedimento está relacionada ao valor subjacente. Para alguns profissionais da saúde só há tratamento quando se faz algo efetivamente e, numa época tão plena de novas tecnologias, estas são usadas como tentação - a de que se está fazendo de fato alguma coisa, aliviando-se a consciência.

Outro ponto a ponderar envolve a questão econômica: é rentável submeter os pacientes a um grande número de tratamentos, mesmo que o resultado seja praticamente nulo, pois aumenta o faturamento. A questão é: quem é que está sendo beneficiado, o paciente, a família ou as empresas de saúde?

Segundo Lépargneur (1999), a distanásia reflete uma atitude orgulhosa de confiança na técnica, uma idolatria da vida, o me do de encarar a morte de frente, representando um ataque contra a dignidade da pessoa. É também um ataque à sociedade, um uso excessivo de energia, que é ainda mais grave quando os recursos são limitados e, em conseqüência, quando se pensa que muitas pessœas não têm direito a uma assistência básica e necessária de saúde, resultando em um grande número de mortes, configurando o que se denominou de mistanásia (Martin, 1993). Esta discussão é fundamental em um país tão marcado pelas desigualdades, com parcos recursos, exigindo a responsabilidade coletiva sobre assistência de saúde. Segundo Fortes (2002), a grande questão que se coloca é o que significa distribuição justa, ou seja, atender a cada pessoa segundo as suas necessidades.

Com o avanço biotecnológico, corre-se o risco de perder o bom senso diante de um paciente com um quadro irreversível e, em vez de se proporcionar a vida, prolonga-se o processo de morrer. Mas, longe de consenso, estas práticas ainda suscitam polêmica, dúvidas e conflitos que demandam conversa e troca de experiências num debate pluralista.

E, finalmente, uma pergunta: do ponto de vista religioso, será que a distanásia não seria considerada uma transgressão à vontade divina, na medida em que se mantém vivo alguém que está praticamente morto? 


\section{Programas de cuidados paliativos - opção à eutanásia, ao suicídio assistido e à distanásia?}

Seriam os cuidados paliativos um caminho entre a eutanásia, o suicídio assistido e a distanásia? Uma possibilidade de operacionalização da ortotanásia? A morte na hora certa?

Pacientes gravemente enfermos que freqüentam programas de cuidados paliativos têm grande possibilidade de terem aliviados seus sintomas incapacitantes e sua dor e há grande preocupação da equipe em relação à qualidade de vida. Assim, pode-se dizer que o movimento de cuidados paliativos traz um grande progresso no que concerne aos cuidados no fim da vida, restituindo o bem estar global e a dignidade ao paciente gravemente enfermo, favorecendo a possibilidade de viver sua própria morte, um respeito por sua autonomia e não o abandonando à própria sorte.

Quando discutimos criteriosamente a morte com dignidade, temos de ficar alertas sobre como isto será entendido no futuro. Devemos lembrar que as intenções de Hitler foram consideradas como uma valorização da humanidade, e muitos se iludiram com as suas belas palavras. O que dificulta anda mais a questão é que pessoas em estado crítico da doença, com perda de consciência, não conseguem participar da decisão sobre a sua própria vida. A humanização da morte não é o seu apressamento, nem o seu prolong amento indefinido. Se a discussão que se propõe é sobre o que seja morte com dignidade, o movimento de cuidados paliativos defende que seja a morte sem sofrimento, nem rápida, nem demorada demais.

A morte relacionada com quadros de demência como é o caso do mal de Alzheimer é considerada como ruim. Aí, uma grande indagação surge: é possível haver uma boa morte? Não se trata, porém, de normatizar o que seria a boa morte, enquadrando os pacientes num padrão.

O que pode ser esboçado, isto sim, é conhecer melhor as diversas facetas da significação da morte e alguns dos medos que a acompanham. Pois bem, entre os grandes temores do processo de morrer, na atualidade, há o de sofrer muito, ter dor insuportável, ver a degradação do corpo, ser dependen- 
te, sobrecarregar a família e deixar grandes ônus financeiros. Os programas de cuidados paliativos buscam amenizar estas questões, mas não as eliminam totalmente, em especial, quando a rede de apoio familiar e social do paciente se encontra reduzida. E, quando o paciente diz que gostaria de encerrar a vida, a equipe não abre o espaço para esta discussão, embora seja bem verdade que é fundamental que a pessoa possa falar sobre seu desejo de morrer, e a finalização dos assuntos pendentes. Entretanto, é importante enfatizar que escutar o desejo de morrer não significa atendê-lo, como já afŕmado anteriormente. Os programas de cuidados paliativos não propõem eutanásia.

Enfim, restam algumas perguntas fundamentais: será que os programas de cuidados paliativos são a solução em todos os casos? Será que estão disponíveis para todos aqueles que deles necessitam? Na França, sim, por lei de 1999, que garante esse acesso. E nós perguntamos: quando isto acontecerá no Brasil?

Finalizando este tópico, e para demonstrar que a discussão está (e estará por muito tempo) em aberto, trago algumas críticas e ponderações sobre o movimento de cuidados paliativos, lançando mão de um artigo de Logue (1994).

A autora esboça uma crítica aos programas de cuidados paliativos, especialmente pelo fato de não abrirem espaço para a discussão sobre o direito de morrer. Embora reconhecendo que esses programas se preocupam com a qualidade de vida e bem estar dos pacientes, pergunta: será que são o melhor encaminhamento para todos os casos de doença grave? Mesmo havendo ênfase na questão da autonomia e controle do paciente, ela questiona: será que é de fato assim? Será que o fim da vida é sempre pleno, com descobertas, com possibilidade de contato com a transcendência - ou esta é uma visão idealizada da morte? Será que não há uma idealização da bela morte nos programas de cuidados paliativos?

A autora continua a expor suas críticas, apontando que os pacientes que participam de programas de cuidados paliativos são ultra selecionados. Muitos outros, com intenso sofrimento, nem chegam a ser atendidos. É um 
programa ideal para pacientes com câncer avançado; já os que têm AIDS em estágio adiantado, com múltiplos sintomas e quadros demenciais, correm o risco de não serem aceitos. Pacientes idosos também podem não participar, pois há dificuldades em cuidar de seus múltiplos sintomas, ficando mais difícil garantir uma boa qualidade de vida. Além disto, embora grandes avanços tenham sido obtidos no caso do controle da dor, muitos outros sintomas ainda não são cuidados de maneira efetiva, como, por exemplo, a fadiga e a solidão, só para citar alguns. Em 16\% dos casos, infelizmente, não é possível sequer o controle total da dor. E mais: são muitas as seqüelas dos opiáceos: enfraquecimento, fadiga, dependência e perda de controle do corpo. A isso tudo, soma -se a sensação de ser uma sobrecarga para a família estão constituídos os principais motivos arrolados para se desejar morrer.

A autora argumenta, ainda, que, embora os tratamentos para prolongamento da vida não ocorram em programas de cuidados paliativos, há alguns procedimentos para controle da dor que são agressivos, citando como exemplo as amputações. Estas últimas podem até ser necessárias para a contenção de um tumor, entretanto, são muito temidas e sentidas como piores do que a própria doença.

Os programas de cuidados paliativos não têm aparelhos para ressuscitamento, nem propõem os tratamentos heróicos das UTIs. Entretanto, não ligar o respirador ou desligá-lo nem sempre leva à morte. Segundo a autora, confirmando o que já foi dito, os programas de cuidados paliativos são muito importantes e ajudam na busca de uma boa qualidade de vida nos últimos dias, mas, de longe, não são a única resposta para a discussão sobre estas questões do fim da vida.

Finalizo com importante ponderação de Lépargneur (1999) que, embora enfatizando a importância do movimento de cuidados paliativos, afirma que, encerrar toda a polêmica sobre eutanásia com o desenvolvimento desses programas é muito simplista, pois é ingênuo acreditar que toda angústia de uma pessoa que pede para morrer esteja relacionada com o fato de ter sua dor não controlada. Propõe que o desejo de morrer possa ser discutido amplamente entre o paciente, familiares e equipe, e, se necessário, em caso de 
conflito, que grupos multidisciplinares de ética possam ser chamados a intervir.

Para encerrar, quero enfatizar que, embora o tema da morte ainda seja tabu, atualmente tem havido grande busca de discussão e reflexões sobre o tema, o que inclui, também, incremento de pesquisas. Assim, é cada vez mais importante discutir aquelas que envolvem pessoas no fim da vida e/ou enlutadas; é, necessário, portanto, abrir espaço para esta reflexão.

Cook (1995) traça um histórico sobre a questão do consentimento informado, trazendo os primeiros exemplos em que a pessoa é consultada sobre se quer ou não submeter-se a uma certa intervenção. Refere-se a um exemplo do século XIX, época em que as cirurgias eram feitas sem anestesia, envolvendo um sofrimento atroz, quando, em 1833, um homem com ferimento exposto na perna se colocou disponível para que observassem o que acontecia. Uma das situações que trouxe profundas discussões sobre a importância do consentimento informado é o que ficou conhecido como o desastre de Lübeck, em que um teste da vacina BCG foi aplicada em 100 crianças, sem que seus pais soubessem ou tivessem dado autorização; isto aconteceu em 1930, e morreram 75 crianças.

Segundo estes autores, houve um grande desenvolvimento destes procedimentos depois que foram divulgadas as atrocidades cometidas na guerra, com as experiências nazistas. As denúncias de Beecher, na Inglaterra e Estados Unidos, envolvendo a questão do uso do placebo: o uso de células cancerosas em crianças com deficiência mental para testar a imunidade em relação ao câncer vieram à tona.

Cook (1995) propôs uma séria revisão de diretrizes para pesquisa, enfatizando a importância do consentimento informado e da preocupação em não aumentar o sofrimento dos pesquisados, pois já era muito grande.

Mais ou menos na mesma época, o Conselho Nacional de Saúde (Brasil, 1996) posicionou-se, arrolando os seguintes princípios norteadores dos estudos que envolvem seres humanos: 
- Beneficência: maximização dos bons resultados para a ciência, a humanidade e diminuição ou evitamento de riscos.

- $\quad$ Respeito: proteção à autonomia da pessoa, honrando a possibilidade da escolha em participar ou não da pesquisa, preocupando-se com o bem estar dos participantes.

- Justiça: distribuição equiitativa dos benefícios e a segurança do que é razoável, não explorando as pessoas e garantindo cuidadosos procedimentos de pesquisa.

O consentimento informado envolve os seguintes aspectos:

- Os participantes devem ter aceitado participar da pesquisa voluntariamente, com base nas informações recebidas.

- $\quad$ Podem se retirar da pesquisa quando desejarem.

- Todo o risco desnecessário deve ser eliminado, incluindo-se os procedimentos físicos invasivos, os psicológicos e os sociais.

- $\quad$ Os benefícios para o indivíduo e para a sociedade devem ultrapassar os riscos.

- $\quad$ A pesquisa deve ser conduzida por pessoas qualificadas.

Todos esses ângulos e possibilidades devem ser analisados cuidadosamente, em especial quando se pensa em pessoas que estão sob grande sofrimento, como pacientes gravemente enfermos, familiares e profissionais de saúde. É necessário um comitê de ética independente do pesquisador.

Uma questão polêmica que surge é sobre a utilização de tratamentos ainda não comprovados e que precisam ser testados, se m colocar em risco a vida das pessoas. No consentimento em participar deste tipo de pesquisas estão envolvidas: decisão voluntária, qualidade da informação dada e sua compreensão.

A decisão deve ser voluntária, sem coerção, sendo necessário verificar se não está havendo nem mesmo alguma pressão sutil. Esta questão fica ainda mais evidente, se as pesquisas são realizadas em hospitais, onde os 
pacientes podem temer que sua não aceitação, desagradando médicos e cuidadores, implique em prejuízo do tratamento. Por esta razão, há um item fundamental no consentimento informado: a garantia de que os não participantes não sofrerão represálias nem alteração nos seus tratamentos, pela recusa em participar de protocolos de pesquisa, e, para os participantes, em caso de abandono.

Por outro lado, o abandono da pesquisa, a qualquer momento, pode ser uma variável muito complicada para o pesquisador, por ter sua amostra diminuída, dificultando o tratamento dos dados. Mas, devem ser sempre considerados os riscos e benefícios de cada participante.

O princípio da confidencialidade garante a privacidade dos sujeitos com a salvaguarda sobre que tipo de informações serão divulgadas. Há casos em que esta privacidade não pode ser garantida.

Para que o consentimento seja dado com propriedade é essencial que as informações sejam completas e precisas. A utilização de jargão deve ser evitada, pois, além de dificultar a compreensão, pode propiciar a ocorrência de confusão e mal entendidos, aumentando o medo e a ansiedade.

Outras questões que se colocam são: pessoas em intenso sofrimento têm a capacidade de exercer sua vontade (ou ter clareza sobre ela) de participar ou não de um protocolo de pesquisa? No caso de não poder dar o consentimento, alguém pode fazer isso por ela? São questões difíceis de responder, e que exigem discussões em comitês de ética, buscando-se as especificidades de cada situação.

E aqui finalizo estas reflexões sobre a bioética nas questões de vida e morte, porém, longe de trazer respostas e, sim, com a certeza de que este campo continua aberto, a cada dia com novas questões a serem debatidas, pois envolvem conflitos, dado que vários pontos de vista são possíveis, demandando constante aprofundamento. 


\section{Maria Julia Kovács}

Kovács, M. J. (2003). Bioethics oncerning life and death. Psicologia USP, 14(2), 115-167.

Abstract: This article discusses fundamental questions concerning the end of life and the proximity of death. Based on the bioethical approach, issues such as quality of life, dignity in the process of dying, and autonomy of choices regarding life in its final moments are discussed. The improvement of medical technology favoured the cure of many diseases and the prolongation of life. When exaggerated, though, it may add suffering to what is supposed to be a benefit, stimulating discussion about complex issues such as: the right to decide about one's own death, euthanasia, assisted suicide and dysthanasia. Clarification and presentation of these topics from various angles are objectives of this article. The possibility of multidisciplinary discussion of the issues presented is also suggested.

Index terms: Bioethics. Death. Euthanasia. Palliative care.

Kovács, M. J. (2003). Bioéthique dans les questions de lavie et de la mort. Psicologia USP, 14(2), 115-167.

Résumé: Ce travail discute des questions fondamentales entourant la fin de la vie et l'approche de la mort. En toile de fond on présente une réflexion bioéthique sur des thèmes complexes, tels que : qualité de vie, dignité dans l'acte de mourir et autonomie dans les choix en relation à sa propre vie dans ses moments finaux. L'avancement de la technologie médicale a favorisé la guérison de maladies et la prolongation de la vie qui, cependant, de manière exagérée, peut amener à ce que la souffrance s'additionne à e qui est proposé comme un bénéfice, stimulant la discussion sur les questions relatives au droit de décider sur le moment de la mort, l'euthanasie, le suicide assisté et ? ? ?. La clarification la présentation de ces thèmes sous divers angles sont les objectifs de ce travail. On propose aussi la création d'espaces pour la discussion multidisciplinaire des questions présentées.

Mots clés : Bioéthique. Mort. Euthanasi. Soins palliatifs. 


\section{Bioética nas Questões da Vida e da Morte}

\section{Referências}

Albom, M. (1997). A última grande lição. O sentido da vida. Rio de Janeiro: Sextante.

Anjos, M. F. (2002). Bioética e teologia. Bioética - Uma perspectiva brasileira [número especial]. Mundo da Saúde, 26(1), 40-50.

Bel Mitchell, C. (1999-2000). Of euphemisms and euthanasia the language games of the Nazi Doctors and some implications for the modern euthanasia movement. Omega, Journal of Death and Dying, 40(1), 255-265.

Canetto, S. S., \& Hollenshead, J. D. (1999). Gender and physician assisted suicide: An analysis of the Kervokian cases, 1990-1997. Omega, Journal of Death and Dying, 40(1), 165- 208.

Chochinov, H. M., Wilson, K. G., Enns, M., Mowchun, N., Lander, S., \& Levitt, M. (1995). Desire for death in the terminally ill. American Journal of Psychiatry, 152, 1185-1191.

Cook, A. S. (1995). Ethi cal issues in bereavement research. Death Studies, 19, 103-122.

Dodge, R. F. (1999). Eutanásia, aspectos jurídicos. Bioética, 7( 1), 113-120.

Engelhardt Jr, H. T. (1998). Fundamentos da bioética. São Paulo: Loyola.

Fabbro, L. (1999). Limitações jurídicas à autonomia do paciente. Bioética, 7( 1), 7-12.

Fortes, P. A. C. (2002). Bioética, eqüidade e políticas públicas. Bioética - Uma perspectiva brasileira [número especial]. Mundo da Saúde, 26(1), 143-147.

França, G. V. (1999). Eutanásia: Enfoque ético-político. Bioética, 7(1), 71-82.

Garrafa, V., \& Porto, D. (2002). Bioética, poder e injustiça: Por uma ética de intervenção. Bioética - Uma perspectiva brasileira [número especial]. Mundo da Saúde, 26(1), 6-15.

Gutman, D. (1999-2000). Physician, hate thyself. Comment on the Kervokian tapes. Omega, Journal of Death and Dying, 4O(1), 275-277.

Hastings Centers. (1987). Guidelines on the termination of life sustaining treatment and the care of the dying. New York: Author.

Hennezel, M. (2001). Nós não nos despedimos. Lisboa, Portugal: Editorial Notícias.

Horta, M. P. (1999). Eutanásia. Problemas éticos da morte e do morrer. Bioética, 7(1), 27-34.

Humphry, D. (1991). Final exit: The practicalities of self deliverance and assisted suicide. Oregon: The Hemlock Society. 


\section{Maria Julia Kovács}

Kaplan, K., \& Bratman, E. (1999-2000). Gender, pain and doctor involvement: High school student attitudes toward doctor.assisted suicide. Omega, Journal of Death and Dying, 31(3), 27-41.

Kastenbaum, R. (1999-2000). Looking death in the eye. Another challenge from doctor Kervokian. Omega, Journal of Death and Dying, 4O(1), 279-286.

Kipper, D. (1999). O problema das decisões médicas envolvendo o fim da vida e propostas para a nossa realidade. Bioética, 7( 1), 71-82.

Lachenmeyer, F., Kaplan, K., \& Caragacinu, D. (1998). Doctor assisted suicide: An analysis of public opinion of Michigan adults. Omega, Journal of Death and Dying, 40(1), 61.87.

Lamb, D. (2001). Ética, morte e morte encefálica. São Paulo: Office Editora.

Lépargneur, H. (1999). Bioética da eutanásia. Argumentos éticos em torno da eutanásia. Bioética, 7(1), 41-48.

Logue, B. J. (1994). When hospice fails: The limits of palliative care. Omega, Journal of Death and Dying, 29(4), 291-301.

Markson, E. (1995). To be or not to be: Assisted suicide revisited. Omega, Journal of Death and Dying, 31(3), 221-235.

Martin, L. (1993). A ética médica diante do paciente terminal. Leitura ético teológica da relação médico-paciente terminal nos códigos brasileiros de ética médica. São Paulo: Editora Santuário.

Mishara, B. L. (1999). Synthesis of research and evidence on factor affecting the desire of terminally ill or seriously chronically ill persons to hasten death. Omega, Journal of Death and Dying, 39(1), 1-70.

Mota, J. A. C. (1999). Quando um tratamento se torna fútil. Bioética, 7(1), 35-40.

Pessini, L. (1999). Eutanásia e as religiões (judaísmo, cristianismo, budismo, islamismo). Bioética, 7(1), 83-100.

Pessini, L. (2001a). Distanásia. Até quando prolongar a vida? São Paulo: Centro Universitário São Camilo/Loyola.

Pessini, L. (2001b). Viver com dignidade a própria morte: Reexame das contribuições da ética teológica no atual debate sobre a distanásia. Tese de doutorado, Centro Universitário Assunção, Pontifícia Faculdade de Teologia Nossa Senhora de Assunção, São Paulo.

Pessini, L., \& Barchifontaine, C. (1994). Problemas atuais de bioética. São Paulo: Loyola. 


\section{Bioética nas Questões da Vida e da Morte}

Potter, V. R. (1971). Bioethics. Bridge to the future. Englewood Cliffs: Prentice Hall.

Schneiderhan, M. E. (1999-2000). Physician.assisted suicide and euthanasia: The pharmacist's perspective. Omega, Journal of Death and Dying, 40(1), 88-99.

Schramm, F. R. (2002). A questão da definição de morte na eutanásia e no suicídio assistido: Bioética - Uma perspectiva brasileira [número especial]. Mundo da Saúde, 26(1), 178-183.

Segre, M. (1999). Atualidades. Bioética, 7(1), 145.

Segre, M., \& Cohen, C. (Orgs.). (1995). Bioética. São Paulo: Edusp.

Stephen, R. L., \& Grady, R. (1992). Case analyses of terminally ill cancer patients who refused to sign a living will. Omega, Journal of Death and Dying, 24(1), 283-289.

Whiting, R. (1995-1996). Natural law and the "right to die". Omega, Journal of Death and Dying, 32(1), 1-26.

Wooddell, V., \& Kaplan, K. (1997-1998). An expanded typology of suicide, assisted suicide and euthanasia. Omega, Journal of Death and Dying, 36(2), 219-226.

Zaidhaft, S. (1990). A morte e a formação médica. Rio de Janeiro: Francisco Alves.

Recebido em 19.11.2002

Aceito em 17.02.2003 